\title{
Communicative functions during the pre- grammatical stage: a case study / Las funciones comunicativas durante la etapa pregramatical: un estudio de caso
}

\author{
Fernando G. Rodríguez \& Silvia Español
}

To cite this article: Fernando G. Rodríguez \& Silvia Español (2019) Communicative functions during the pre-grammatical stage: a case study / Las funciones comunicativas durante la etapa pregramatical: un estudio de caso, Infancia y Aprendizaje, 42:2, 413-458, DOI: 10.1080/02103702.2019.1585654

To link to this article: https://doi.org/10.1080/02103702.2019.1585654

Published online: 11 Apr 2019.

Submit your article to this journal $\sqsubset$

Џll Article views: 32

View Crossmark data ¿ 


\title{
Communicative functions during the pre-grammatical stage: a case study / Las funciones comunicativas durante la etapa pregramatical: un estudio de caso
}

\author{
Fernando G. Rodríguez and Silvia Español ${ }^{\mathrm{b}}$ \\ ${ }^{a}$ Universidad Abierta Interamericana; CONICET -; ${ }^{b}$ Instituto de Investigaciones de \\ Ciencias Sociales de América Latina (IICSAL/FLACSO)
}

(Received 17 July 2018; accepted 19 February 2019)

\begin{abstract}
This study contributes empirical evidence regarding communicative functions in the pre-grammatical period. The aim was to explore these functions in child-adult dyadic interactions during what in language acquisition research has been called the two-word period. The study draws from the data corpus of a child 19-29 months old and the system of sign categories (gestures, non-verbal vocalizations, verbal vocalizations, uni- and bimodal compositions) developed by Rodríguez \& Español. In order to study the communicative functions in this period, an observational code was developed in accordance with Strauss and Corbin's Constant Comparative Method, which is suitable for encompassing the entire repertoire of a child's sign use. The study in general allowed some functions absent in adult communication to be identified, and the qualitative analysis in particular revealed a use of semiotic resources that supports the idea of a cognitive processing structure common to gesture and word.
\end{abstract}

Keywords: developmental semiotics; gesture; vocalization; word; communicative functions

Resumen: Este trabajo aporta evidencia empírica sobre las funciones comunicativas en la etapa pregramatical. Su objetivo es explorar estas funciones en las interacciones diádicas niño-adulto durante el período denominado, en la investigación sobre adquisición del lenguaje, de dos palabras. Se utilizó el corpus de datos de un niño entre 19-29 meses y el sistema de categorías para los tipos de signos (gestos, vocalizaciones no-verbales, palabras y composiciones uni- y bimodales) recogidos por Rodríguez y Español. A los efectos de estudiar las funciones comunicativas en este periodo de tiempo, se confeccionó un código de observación, siguiendo el Método Comparativo Constante de Strauss y Corbin, que abarcara todo el repertorio de los usos sígnicos del niño. Se identificaron funciones ausentes en la comunicación adulta

English version: pp. 413-434 / Versión en español: pp. 435-456

References / Referencias: pp. 456-458

Translated from Spanish / Traducción del español: Mary Black

Authors' Address / Correspondencia con los autores: Fernando G. Rodríguez, Universidad Abierta Interamericana, Lago Lácar 505, Bella Vista, prov. de Buenos Aires, Argentina. E-mail: fgrxyz@gmail.com 
y el análisis cualitativo reveló un uso de recursos que avala la asunción de una estructura de procesamiento cognitivo común al gesto y a la palabra.

Palabras clave: desarrollo semiótico; gesto; vocalización; palabra; funciones comunicativas

The communicative functions of language have been amply addressed, discriminated and debated (Jakobson, 1960; Kerbrat-Orecchioni, 1986). However, there is a relative dearth of studies of communicative functions in the pre-grammatical period. When they are researched, the approaches are somewhat partial and focused on certain types of signs at the expense of others (gestures, vocalizations, words, gesture-word compositions). In one prominent study, Crais, Douglas, and Campbell (2004) analysed the functions of deictic and representational gestures from when they first appear until the age of 24 months, providing valuable information on children's semiotic resources. Other studies have chosen to limit themselves to certain specific functions, traditionally the protoimperative and proto-declarative functions, without considering other uses of signs (Cochet \& Vauclair, 2010; Romero Andonegi, Etxebarria Lejarreta, de Pablo Delgado, \& Romero Andonegi, 2017). Yet others, however, have extended beyond the boundaries of the strictly communicative to encompass nonintersubjective cognitive functions (Delgado, Gómez, \& Sarriá, 2010; Dupertuis \& Moro, 2016; Español, 2006); these studies include self-directed gestures, which are assigned an important role as tools of thinking and of early semiotic development, but whose meaningful value does not immediately imply that they are communicative signs. If the communication process is considered to divide the roles of sender and receiver into two different subjects (Rodríguez, 2017; Romero Andonegi et al., 2017), it is important to maintain the distinction between processes of self-regulation and communicative processes. Nonetheless, the gesture of pointing in particular has recently revealed more complex uses than those previously identified (Tomasello, Carpenter, \& Liszkowski, 2007; Rodríguez, 2009). In any event, apart from the controversies, the above considerations, coupled with the general progress in early childhood research and the increasing interest in the pragmatic aspects of communication, suggest that communicative functions are a factor that enables the child to develop interpersonal relationships. And yet they are still an underexplored field.

Along with the relative scarcity of empirical research on communicative functions in early childhood, studies on the development of semiotic skills in childhood tend to concentrate on two essential periods: on the one hand, in the holophrastic period (when the child is capable of producing their first isolated verbal signs, while at the same time combining these verbal signs with gestural signs, giving rise to the first composite communicative structures), and on the other, the early grammatical period (when a certain skill in accommodating verbalizations to language rules can be seen). However, an intermediate period, called the two-word period (a juxtaposition of lexical elements), is extraordinarily important, given that this is when the shift occurs from agrammatical to grammatical compositions. This period has hardly been examined outside certain 
worthy efforts concentrated on a particular semiotic skill (gesture: Andrén, 2010; gesture and word: Zlatev \& Andrén, 2009). A multimodal examination of this period is still indebted to the development of childhood semiosis. Just recently, Rodríguez and Español (2016) considered all the semiotic options of the oral and gestural modalities: gestures, word and non-word vocalizations, and compositions using one modality (gesture-gesture, vocalization-vocalization) or two modalities (gesture-vocalization). This study aims to make up for this threefold deficit — chronological, thematic and perspectival — by studying the functions in the communications of a child based on the set of semiotic options in the oral and gestural modalities present in the two-word period.

\section{Communicative functions before grammar}

Towards the beginning of the second year of life, a child gestures and verbalizes at the same time, or in sequences that are temporally and semantically integrated. These semiotic juxtapositions of two different sending modes have been recognized as being the earliest forms of composite signification (Butcher \& Goldin-Meadow, 1993). Thus, the general process of language acquisition (taking language as a grammaticalized lexical structure) goes through a pre-grammatical period in which gesture and word support each other before the subject is capable of stringing together solely linguistic signs. Detecting these combined uses was an important contribution to the exploration of studies in developmental semiotics, but in order to gain a broader understanding of the child's semiotic world, the study of the formal configuration of the communicative patterns must be coupled with the functions with which the signs are used in an effort to interact.

It is common to deny the usefulness of distinguishing and listing communicative functions (or, in theory, functions of language, since the categories used to address the development of communication are traditionally mined from there, a procedure which, however, significantly limits the research on language development). The classical argument is that the functions of language are not mutually exclusive, and that all messages sent ineluctably imply more than one function, meaning that categories always overlap somewhat. However, this cannot be used as an objection to the accepted fact that children learn their mother tongue precisely to bond with others, and that without this pragmatic motivation it would be difficult to explain their interest in learning something that demands time and effort. If we assume that language serves the social nature or condition of human beings, it makes no sense to consider categorization problems a sufficient obstacle to engaging in an in-depth study of the communicative functions. In other words, it is unacceptable that operationalization difficulties could jeopardize the theoretical progress on the object of study.

The problem of whether the categories used to research linguistic communication are appropriate to also research communication per se, a realm where words are confused with dissimilar signs, is compounded by the fact that the communicative and linguistic functions may not be the same in adult subjects with grammatical capacity and in small children who have only recently begun acquiring their first 
words. For this reason, it is essential for the observational code to accommodate its object of study and the period being studied.

The systems of observational categories to evaluate communicative functions usually lead to Bruner and Bühler on the psychology side and to Jakobson and Halliday on the linguistics side. Bühler (1934), a pioneer in developmental psychology, established a triad of basic functions, namely expressive, appellative and representative, which focused respectively on the foregrounding of the grammatical first, second and third person (the subjective utterance, the quest for a receiver and the reference to a state of things envisioned as a reference). However, this model was limited and omitted other variations in the use of signs. Jakobson (1960) contains a scheme enriched with the phatic function (in which the content of the message is unimportant and what matters the most is preserving the bond/channel of interaction), the poetic function (which focuses on attention to form) and the metalinguistic function (in which communication is split into two levels, object language and metalanguage, which illustrates how one utterance can be the motive for another one for which the first acts as a referent). In turn, Austin (1962) completed this list by stressing a point that was neglected by all previous studies, namely the idea that language is not only a tool for expressing a given content but also simultaneously a means of realizing actions (the executive function in which, for example, when saying 'I promise', one would unfailingly be promising). Bruner (1981), an attentive observer of early childhood semiosis, reorganized the field by positing three functional orientations, which in turn encompassed other subordinate functions: (1) behaviour regulation (request for objects, actions or claims); (2) joint attention (comment, request for information); and (3) social interaction (representational gesturing, quest for attention and social games). His scheme dissolves Bühler's agentiality-mutuality-referentiality and replaces it with an ideal of omnipresent duality under the intentions of demand, inform and share. Also attentive to the vicissitudes of development, Halliday (1975) interpreted that there are seven irreducible functions in child communication: instrumental (related to the sender's needs), regulatory (on others' behaviour), interactional (aimed at disinterested contact with others), personal (equivalent to the expressive function), heuristic (to gain greater knowledge of the immediate world), imaginative (aimed at fictional creations) and representational (with the desire to let the interlocutor know something). This set is divided between the group of functions that help the child meet their most pressing material and social needs (the first four) and mutual understanding about the world (the others). In a second phase of development, mathetic functions (language as a cognitive tool) and pragmatic function (use related to the regulation of one's own behaviour) are added. In a third instance, Halliday adds what he calls macro-functions of language: ideational, interpersonal and textual (which entails the insertion of verbal units into increasingly complex contexts).

It is evident that the different categorizations show overlaps (see Table 1), as well as particularities. The problem of choosing which one to adopt as a parameter for observation work cannot be resolved by evaluating their intrinsic worth (which they all have) but instead must be based on the objective of each specific study. For this reason, the classifications of Bühler and Bruner (both, in essence, with three kinds 
Table 1. Comparison between other systems of categories mentioned and the system used in this study.

\begin{tabular}{|c|c|c|c|c|}
\hline BÜHLER & BRUNER & HALLIDAY & $\begin{array}{c}\text { JAKOBSON } \\
\text { AUSTIN }\end{array}$ & THIS STUDY \\
\hline \multirow{3}{*}{ representative } & \multirow{3}{*}{ joint attention } & representational & \multirow{3}{*}{ referential } & declarative $*$ \\
\hline & & heuristic & & \\
\hline & & imaginative & & informative $*$ \\
\hline \multirow[t]{2}{*}{ appellative } & social interaction & interactional & \multirow[t]{2}{*}{ conative } & \multirow[t]{2}{*}{ conative } \\
\hline & behaviour regulation & regulatory & & \\
\hline \multirow[t]{2}{*}{ expressive } & social interaction & instrumental & \multirow[t]{2}{*}{ expressive } & expressive \\
\hline & behaviour regulation & personal & & attitudinal $*$ \\
\hline \multirow[t]{5}{*}{ - } & \multirow[t]{5}{*}{-} & \multirow[t]{5}{*}{ - } & phatic & phatic \\
\hline & & & - & echo * \\
\hline & & & poetic & $?$ \\
\hline & & & metalinguistic & $?$ \\
\hline & & & executive & $?$ \\
\hline
\end{tabular}

Note: $(*)$ new/reformulated categories in this study. (?) unlikely categories in this period. The dubious function and the other function, methodological categories, are omitted.

each) seem somehow to be lacking all the utilities that the small child can extract from their complete range of communicative resources. To the contrary, Halliday distinguishes types which we believe can be condensed in a single category (such as instrumental and regulatory), and his macro-functions go beyond communicative acts, which are precisely what our study aims to shed light on. Jakobson's classification (with Austin's contribution on the executive function) seems richer in its range of options, yet it is designed for mature speakers in possession of competences beyond the child's semiotic competence (the metalinguistic and poetic functions both assume the capacity to bend or flex the language around itself, in the former to talk about language itself, and in the latter to embellish the formal vehicle). Nonetheless, it is the most convenient classification as a starting point: in practical terms, because it is the most widespread and allows for a psychological-linguistic dialogue; in theoretical terms, because it offers a range of functions that are more clearly distinguished (even if our first recordings and decoding efforts revealed deficiencies and led to adjustments - as explained in the observational code; see below).

In the particular terrain of semiotic studies in early childhood, classification by Bates, Camaioni, and Volterra (1975) tends to last even today, distinguishing between two basic uses of gesture: declarative and imperative (e.g., EsteveGibert \& Prieto, 2013; Murillo \& Belinchón, 2013; Romero Andonegi et al., 2017). Some studies already mentioned concerning the uses of the pointing gesture (Tomasello et al., 2007) or proto-interrogative gestures (Rodríguez, 
2009) have not yet been integrated into a systematized categorization. The codification by Sarriá Sánchez (1991) is worth highlighting; it proposes a meticulous, exhaustive, multidimensional tool for the preverbal period, but since it takes the natural category of 'intentional communicative act' as the common classification unit, it does not distinguish between communicative actions and gestures, rendering two different stages in the acquisition process of semiotic skills homogeneous. Indeed, she does consider giving as a gesture, which certainly constitutes an essential moment in the semiotic progress of the child, but it does not yet meet the condition of being a sign in the strict sense. In the opinion of the community of experts, the act of giving is located in a nebulous area between the categories of action and gesture. Actions can have communicative purposes, so they can be taken as gestures; however, some authors distinguish between the two based on the Vygotskian hypothesis that the child's first gestures stem directly from a primitive communicative structure - incidental communication created for the child's actions and their interpretation by the adult - through changes in the form and function of the actions on objects (Andrén, 2010; Clark, 1978; Rivière \& Español, 2003; Rivière \& Sotillo, 1999). Following this hypothesis, Español (2004) provided a detailed description of the genesis of the gesture of showing (for the specific case of the gesture in which the child, with an object in their hand, presents it to the adult's eyes by subtly moving it, without actually giving it or expecting it to be taken), as a transformation of the act of giving, and reported on the intermediate forms that characterize the process. Within this theoretical framework, giving is the action (clearly a communicative one) from which the gesture of showing stems (for a different version, see Rodríguez, Moreno-Núñez, Basilio, \& Sosa, 2015).

After reviewing these variations, we were led to develop an observational code sui generis which is fed by the categories from the previous studies and reexamines them to accommodate them to our period and objectives (providing the nominal and operational definitions which tend to be missing in similar studies).

The study we are presenting seeks the overarching objective of making an exhaustive description of the communicative functions of gestures and vocalizations during the two-word period (19-27 months). This period, which formerly enjoyed attention for being when the child was able to string together two different signs for the first time, has lately been ignored after it was discovered that the presence of gesture-word compositions was verified in the previous period, called holophrastic, which means that the link between two communicative signs does not have to expect two verbal terms to be strung together (Butcher \& Goldin-Meadow, 1993). However, precisely because of its nature as a link between agrammatical compositions and the emergence of the first structures with morphosyntax, the two-word period is interesting in a different sense. Its intermediate timeframe is what makes it an appealing period to research the shift between both communicative levels, thus making it particularly fertile ground for the psychology of early childhood development (F.G. Rodríguez, 2017). In order to extend the exploration to the time when the systematic studies on language development begin (30 months - see Andrén, 2010), the observations in our study were extended to the two following months, for 
which there is also scant information, thus encompassing from 19 to 29 months of age.

Even though a study of this type does not have a hypothesis in the strict sense (Hernández Sampieri, Fernández Collado, \& Baptista Lucio, 2006), we start with the assumption that communicative multimodality is the fundamental matrix of early developmental semiotics, its presence is verified throughout the entire period examined, and therefore the communicative functions at this age reflect subtle cooperation between the oral and gestural registers.

\section{Method}

In this section, we shall outline the methodology, first by describing the type of study conducted, then by sharing information on the participants, and finally by explaining the materials and procedure used.

\section{Type of study}

A developmental, longitudinal study on a single case was conducted. This type of study has a longstanding tradition of precursors (Brown, 1973; Hernández Pina, 1984; López Ornat, Fernández, Gallo, \& Mariscal, 1994) and is methodologically justified because it makes it possible to avoid 'the interpretation problems caused in experimental procedures by cutting off the developmental continuum between two points' (López Ornat, 1994, p. XVI). This study used the observational corpus of adult-child interactions and the system of categories for types of signs found in Rodríguez and Español (2016).

\section{Participants}

An adult-child dyad. Bruno (henceforth B) is an Argentine boy from the city of Buenos Aires, who was born into a middle-class house with a brother almost three years older than him, professional parents and a monolingual family. He was not born prematurely, nor has he been diagnosed with any developmental delay. He is the younger son of the first author. There are important precedents for this methodological decision (Forrester, 2010; Hernández Pina, 1984; López Ornat, Fernández, Gallo, \& Mariscal, 1994; Piaget, 1937/1988) and a clear theoretical justification: the everyday contact ensures that exchanges can be recorded with the guarantee that the undeveloped child's language, the idiolectal elements it may have and the tacit contextual characteristics that condition the understanding of the situational behaviour and expression will be optimally decoded. The child's age in the first session - following the Piagetian nomenclature of year;month (day) was $1 ; 7(13)$, while in the last session it was $2 ; 5(1)$.

\section{Materials and procedure}

Fifteen sessions of everyday interactions by the child-adult dyad were recorded, each lasting 30 minutes, every 20 days during the period spanning the age of 19 
to 29 months. Different toys were used in the sessions (cars, balls, blocks, fitting toys, etc.), storybooks and everyday objects found in a middle-class home, varying them according to the occasions and the sites (child's bedroom, livingdining room, kitchen, etc.). In all cases, the adult interacting with the child (father, mother and nanny, alternating sessions) initiated the exchanges by suggesting activities (reading a story, playing with toy cars, etc.), and then the session was released to the child's spontaneity, always within a framework of free interaction so that the child could decide on the theme and ways (for example, one time his interest was spontaneously focused on the coloured letter magnets on the refrigerator, and that inspired a long period of play). As a general rule, the session happened with the adult interlocutor and the child seated on the floor facing each other at a distance of approximately 1.5 metres, ensuring that the bodies were always within the frame of the camera's image. The alternation of the adult interlocutors sought to cancel out the possibility that there was any bias in the style of the exchanges based on the partner. All the sessions were recorded by the father-researcher or by the child's mother, and they were both attentive to regulating the zoom when the child occasionally stood up or moved about. A Sony DCR-DVD505 camera was used, a common camera in the child's family milieu (so it was unnecessary to engage in any adaptive activities).

Only the child's expressions that were intentionally directed at the interlocutor were taken as communication. The study used the system of categories for types of signs (gestures, non-verbal vocalizations, words, uni- and bi-modal compositions) contained in Rodríguez and Español (2016). The vocalizations include a category of unintelligible modulations, cases in which it was impossible to say exactly which of the categories an utterance should be assigned to (if indeed any) because of the deficient diction common to this age. In order to analyse the communicative functions with which the types of signs were used, an observational code was developed for these functions via the Constant Comparative Method (Strauss \& Corbin, 1998). The definitive system of categories for communicative functions (cfr. Table 1) was applied to the categories mentioned above, and the frequencies of each function for all the child's communicative interventions were tallied. No computer programs were used to code them; instead, two coders were used (the authors of this study), who first worked independently and later debated the cases in which there was a discrepancy. The following steps were taken: (a) each session was reviewed by the two coders independently; (b) any events in which there was disagreement were discussed until a consensus was reached; (c) any events in which no consensus was reached were eliminated from the tallies. This procedure is consistent with those used in studies of social interaction (Español, Bordoni, Martínez, Camarasa, \& Carretero, 2015; Forster \& Iacono, 2013; Jonsson et al., 2001; Martínez, Español, \& Pérez, 2018). For the data analysis, the SPSS 20.0.1 statistical program was used. Given the level of measurement of the variables, the Spearman's correlation coefficient was calculated.

The classification adopted (Rodríguez \& Español, 2016) encompasses not only the dimension highlighted by types of signs, but also a second dimension of categories to jointly tally semiotic units of the oral and gestural modalities 
according to their generic semantic role. In this way, the total production of gestures and vocalizations was organized into: (a) denotative signs (descriptive or referring to a real/virtual entity); (b) functional signs (aimed at connecting or modifying the meaning of other signs: linking, affirming and negative signs); (c) expressive signs (carriers of affective, non-referential, semantics); (d) dubious signs (in which it was impossible to determine in which of two categories they should be classified: e.g., whether the diction 'o_to' corresponded to the adjective 'otro' [other] or a certain closed modulation of 'auto' [car]; and finally (e) other signs. The 'dubious' category should not be confused with the 'unintelligible' category; while 'dubious' implies ambiguity, 'unintelligible' means that it was impossible to detect any semantic load in the vocalization. The generic intermodal categories (a)-(e) group the signs together by their basic meaningful purposes, that is, what the signs themselves are used for, according to their predefined profile - to denote, link, express emotions, etc. - beyond the specific uses with which the senders employ them in each case. This other level of meaningfulness should not be confused with the earlier, more basic one.

At this point, it is worthwhile to provide more specific information on the transcriptions of the child's expressions. Depending on the uses, the character ' + ' is used to indicate the juxtaposition of signs in bimodal compositions (such as in pointing + 'Acá' [here]) or to indicate the kinds of components in similar compositions (representational gesture + noun). The slashes, '/, , are used to explain the meaning of an oral or gestural expression which could not be understood by its literal transcription ('muto'/mucho/[a lot]). The underscore sign, ', ', is used to indicate the absence of a phoneme ('E_te'/este/[this]) and the dash' '-' indicates that an entire syllable or even more phonematic units are missing ('-yó'/cayó/[he/ she/it fell], 'pe-ta'/pelota/[ball]). The pipes '|' separate the utterances of the different participants in a dialogue ('¿Este es tuyo?’ [Is this yours?] | No' [No]).

\section{Observational code}

Based on the classification of the types of signs and the generic categories indicated, and via the iterative observation of the material recorded, our codification of the communicative functions was adapted to the types of signs that the child effectively produced. The categories which the case rendered superfluous for this period were eliminated, others were created (the functions of 'request' and 'question' — López Ornat et al., 1994 — and proto-interrogative gestures — Rodríguez, 2009 — were integrated as a conative function), and other new ones were discerned. The main new theoretical contributions of our system of categories are the following:

- The referential function (Jakobson, 1960) was split into the declarative and informative functions, which respectively encompassed first the allusivenominative uses (naming an object; if it was a gesture, highlighting that it was identified), and second the predicative function (saying something about the referent: 'E_te titito'/este chiquitito/[This small], 'E_te rrrrr/ 
esto (un auto) hace rrrrrrr (al andar)'/[This (a car) does rrrrr (when it goes)]). The distinction lies in the implied cognitive differences and in the importance of the progress from allusion, after an obviously previous recognition, to attribution (Coseriu, 2015).

- An attitudinal function was distinguished in cases in which the subject takes a subjective stance towards a propositional content, and when they do not entail expressive communications per se (subjective expressions motu proprio).

- An echo function was distinguished which encompasses expressions, primarily verbalizations, repeated by the child without any other apparent aim than to master new sounds, pronounce them for the first time or consolidate the link between the string of phonemes and their semantic correspondence.

Below we outline the nominal and operational definitions of each functional category, which are generally absent in specialized publications, leading to mistakes in understanding the results. It is essential to once again remark that there is almost always some overlap among the kinds of functions (Jakobson, 1960). In the coding, the predominant function was always marked. Only when the researchers considered that there was more than one main function were both marked. The operational definitions are outlined below with the abbreviation OD.

\section{Declarative}

This consists of naming or indicating, depending on whether it is a vocalization (word or non-word) or a gesture. It provides no information on the referent but instead is limited to mentioning it or deictically alluding to it. OD: it encompasses all gestures, vocalizations or compositions which give attention to an object or a situation. E.g., 'Auto' (car): gesture of pointing to the referent.

\section{Informative}

This consists of attributing a predicate to a subject. The distinction between the declarative and the informative functions lies in the fact that while the former entails recognizing and naming an object or event, the latter is fundamentally descriptive. The difference between naming — 'esto' (this), 'pelota' (ball) — and saying something about 'this' or the 'ball' is a valid indicator that the child has begun to compose two different meaningful units. OD: it encompasses all gestures or vocalizations that attribute a predicate of some kind to an object or a situation (to a grammatical subject, either tacit or explicit). E.g., 'Auto lindo' (nice car); pointing to the car + 'romp_ó'/se rompió/(it broke). After a question from the adult which requires objective information ('¿Esto es chiquito?' [Is this small?]), it is assumed that the response ('si'' [yes], 'no' [no] or any other) performs an informative function, even if it contains just one sign (when predication usually implies at least two). This happens because the child is the one who, after having cognitively linked two 
decoded representations ('esto' [this] plus the representation of smallness), actually judges whether or not the question is right. The verifying information comes from the child, even if the oral construction is made by the adult. This verification informs, just as when the response entails more than a monosyllabic affirmative/ negative and supplies information that the question did not: '¿Dónde va esto?' (Where does this go?) | 'Acá' (Here); '¿Qué es eso?' (What is that?)|'Topa' (/pelota/) (ball).

\section{Conative}

This consists of asking the interlocutor for something from him or the surroundings. OD: it encompasses all gestures or vocalizations which ask for or demand an action, word, object, etc. E.g., 'dame' (give me) or deictic gestures (pointing, showing, requesting, etc.)

\section{Expressive}

This consists of the emotional use of communicative resources. Even if pure expression is represented in language by interjections (Jakobson, 1960), no simple or complex utterance in natural language can be decoupled from the affective nuances with which it is uttered. However, this function only encompasses that communication in which the emotional load stands out above the message. OD: it encompasses any expression with gestures/vocalizations where the emotional factor is the most prominent in terms of intentionality. E.g., ' $\mathrm{P}$ Posh malo!'/vos malo/(You bad!), said with a raised voice and an emphatic gesture of hitting the hands on both knees.

\section{Attitudinal}

This consists of the subjective marking of a stance with regard to a given content, in assenting to or refusing proposals, suggestions or orders from the interlocutor. For example, in this dialogue: '¿Querés más sopa?' (Do you want more soup?) | 'Sopa no' (Soup no), the stance with regard to the adult's offer is negative. The same function is fulfilled with a gesture of rejection with the hand or head. This is not a communicative function in referential terms (judgement of true or false) but an unchallengeable stance: the subject's refusal/assent of the subject is not subordinated to anyone else's confirmation, since it lacks objectivity. OD: any communication which displays a stance with regard to a given ideational-semantic content. In contrast to the expressive function, it is not primarily emotional. It encompasses expressions in which the subject somehow locates her/himself with regard to a specific fact or request. Once again, just like for the informative function, the utterance-content can come from the adult ('¿Querés agua?' [Do you want water?]) and the child's participation can be limited to responding yes/no. The difference with this category is whether the 'yes' or 'no' is supported on an observable, objective fact (ultimately, an erroneous response can be corrected, if needed), whereas here the 
individual's disposition towards a fact or proposal at the moment is expressed. In the attitudinal function, communication is only conditioned by the authority of the first person.

\section{Phatic}

This consists of the use of expressions meant to reinforce, open or maintain the communication channel, or to establish or interrupt communication. It only provides superficial information in the guise of semantic-less protoconversations documented since the age of two months old (Trevarthen, 1980). OD: it encompasses any communicative exchange in which the content of the message is not an essential part of the interaction (typically greetings and rhetorical courtesy formulas: 'Buenos días' [Good day], ¿Qué tal el trabajo?' [How is work going?]). 'Gracias' (Thank you) and ‘iSalud!' (Bless you!) after sneezing are the expressions expected in a child.

\section{Echo}

This consists of communications in which the child repeats their interlocutor without any apparent use. It can include new words which the child is trying to modulate and add to their mental lexicon (efforts which are geared towards vocabulary mastery), as well as attempts to repeat a known word. In all cases, the final segment of what the interlocutor expressed is repeated. This function should not be confused with the phatic function, because while the latter seeks to keep the communicative channel open, the echo function inevitably implies (OD) an immediate total or partial repetition of the interlocutor's expressions without any meaning in the semantic interaction. E.g., the adult states: 'Me parece que no' (I don't think so) and the child repeats: '-ece que no' (-don't think so). For cases in which the echo-verbalizations come with an interrogative tone, as if the child is asking if they are repeating it properly, a parallel echo and conative function has been assigned.

\section{Dubious}

This encompasses cases of communicative utterances whose function cannot be determined (not those in which the coders did not agree, but instead those in which they agreed that the communication could not clearly be assigned to a given category).

\section{Other}

This encompasses cases in which intentional gestures or vocalizations are issued which cannot be included in the other categories.

The presence of the metalinguistic, poetic or executive functions from the classical categorization of linguistic functions (Jakobson-Austin) could not be 
expected in the period studied. With regard to the metalinguistic function, all evidence leads us to believe that a child with few words who primarily communicates in a bimodal fashion still lacks sufficient awareness of language to be able to split it into the two planes of use and mention at the same time. The poetic function, in turn, entails strategies that are attentive to the form of the message and to the selection and combination of signs (Jakobson, 1960). With a vocabulary that is still quite limited, it seems difficult to assume that the child would have the ability to select between two similar terms, for example: steed/ horse, using aesthetic criteria. With regard to the executive function, which is dependent on certain verbs ('promise', 'swear', 'inaugurate' — performative verbs) being used in the first person in the present indicative tense, nothing suggests that examples of this could be found in the period studied.

\section{Results}

A total of 5,105 interventions by the child were recorded, with a total of 1,390 gestures and 5,832 vocalizations. The number of vocalizations is higher than the number of interventions, since each intervention could include more than one sign. Table 2 shows the detailed data on each session for these three generic variables, as well as the frequencies of the different kinds of vocalizations (nonword vocalizations, word vocalizations and unintelligible). For reasons of space, only the data on the sign categories which show correlations with the communicative functions and those that allow these correlations to be read contextually are included.

As can be seen in Table 2, vocalizations show a higher total frequency than gestures throughout the entire period. This reveals the child's general preference for the oral modality in his interventions in every session. However, a positive correlation was found between gestures and total vocalizations $\left(r_{s}(14)=.554 ; p<.05\right)$.

The frequency of non-word vocalizations was always lower than the frequency of word vocalizations, and the difference between them increased in each session, in accordance with the developmental expectations. Likewise, unintelligible vocalizations remained at a relatively constant frequency throughout the period, with a slight increase after session 8 .

The frequencies of the different communicative functions are shown in Table 3.

All the functions distinguished in the observational code were present throughout the entire period. Somewhat over one-fourth of the child's communications fulfilled the informative function (27\%), and this increased considerably after session 8 . That and the echo function are the ones that showed the highest increase in frequency compared to the other functions, which had irregular profiles without any clear trend. During the entire period, the phatic function showed particularly stable behaviour, with the lowest frequencies in almost all the sessions. The declarative function had the second-highest frequency of all $(14.4 \%)$, followed by the other function $(11.8 \%)$ and the conative function $(11.5 \%)$. As a whole, the dubious function and the other function, which 


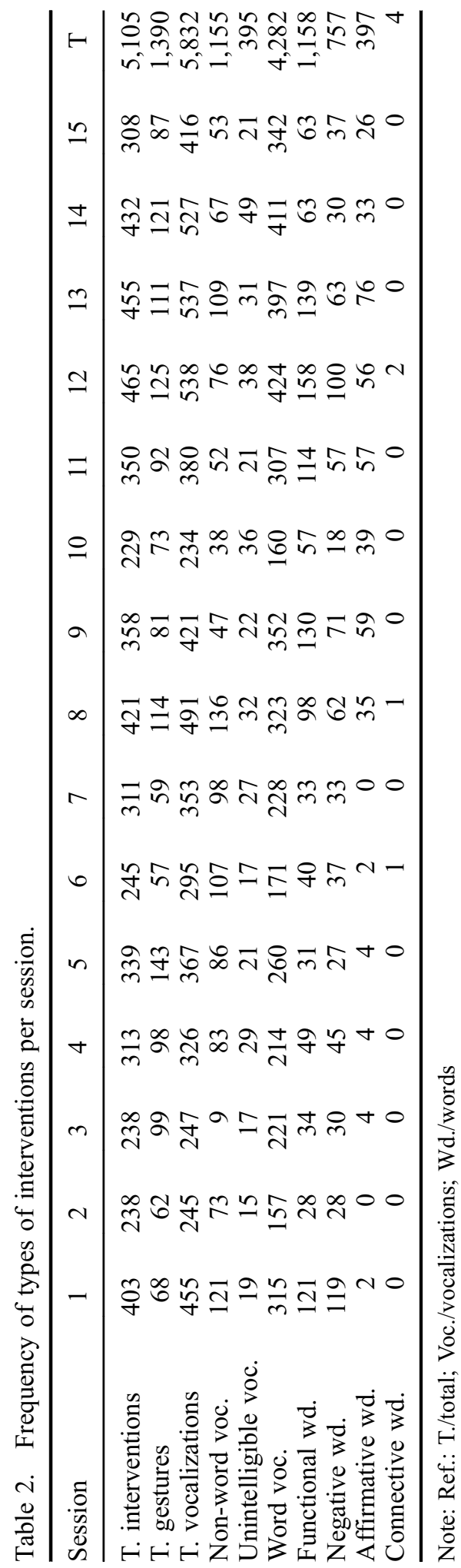




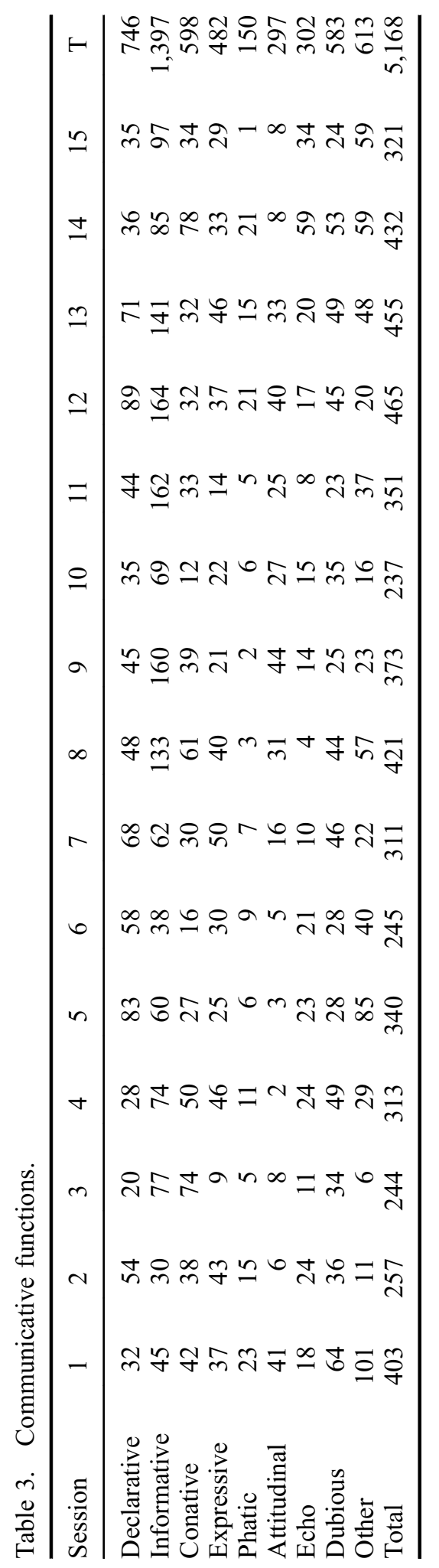


comprise the sub-group of communications without a specific function, showed a total absolute frequency of $23 \%$, which places them together as the second most common functions after the informative function.

No correlations were identified between types of functions and total gestures or vocalizations. However, there was a statistically significant correlation $\left(r_{s}\right.$ $(14)=.735 ; p<.01)$ between the informative function and functional words (comprised exclusively of affirmative and negative adverbs) and between the attitudinal function and these functional words $\left(r_{s}(14)=.820 ; p<.01\right)$. The expressive function also revealed a correlation with the variable of non-word vocalizations $\left(r_{s}(14)=.671 ; p<.01\right)$, a result which fits with non-word vocalizations' status as emotional expressions.

At the same time, the qualitative analysis of the semantic-pragmatic particularities of the child's interventions revealed features of his semiotic productions and functions which would have been impossible to discern in the quantitative analysis.

For the declarative function, which encompasses only referring expressions, cases were found of redundant bimodal compositions (with the same semantic content: pointing + verbalization 'esto' [this]) and of word compositions. In theory, these two compositional varieties may seem to fit the informative function, as they involve two signs (format for proto-propositional constructions, an entity/subject structure and an attribute/predicate structure — 2;1 [28]: 'E_te -ande'/este [es] grande/[This (is) large]). However, both units could point to simple nomination $(2 ; 1$ [28]: 'E_te auto' [This car], a case in which the demonstrative element discriminates by the proximity of the object mentioned). The 'this-here' pattern at the foundation of all declarative utterances is different from the idea of a 'this-so' pattern ('Esto [es] grande' [This (is) large]) or from the 'this-something' pattern ('Esto [es un] perro' [This (is a) dog]), cases in which a sign informs about a different sign (grammatical subject). Even though the most common kind of informative function is expressed via compositions, the study showed that it could occur with isolated signs. A question can deploy all the meaningful contents needed without informing about anything, and the subsequent response can be the informative agent even if it contains a single communicative element. In 2;3 (25), the adult asks '¿De qué color es este lápiz?' (What colour is this pencil?) and the child responds: 'Verde' (Green). Even if the informative elements belong to the question that he has not asked, the child's knowledge is what transforms the whole into an affirmation: /este lápiz es verde/(This pencil is green). The same happens with mere affirmation or negation: ‘¿Esto es azul?' (Is this blue?) | 'Sí’ (Yes). Therefore, the informative operation comes from the child, even when his contribution in terms of utterances is just a single word.

The conative function was represented by orders and requests, both verbal and gestural, with isolated and composite signs (pointing gestures, asking with open hands for requests, or demanding with the act of reaching or grasping, either alone or together, usually accompanied by a verb like '_ame'/dame/[give me], the name of the object or its respective pronoun, alternating between 'yo' [I] and 'mí' [me]). 
The expressive function was embodied in emphatic gestural or oral expressions (words or interjections) in which B made his emotional state known. He repeatedly slapped his knees to make a given expression more powerful ('imío!' [mine!], '¡eh!' [hey!]), or he raised his voice until he was yelling (2;2 [10]: 'No toques' [Don't touch that] | 'Sí toque'/sí toco/[Yes, I touch!]), or he tried to appease to insinuate that he was innocent when questioned (2;2 [10]: '¿Quién se hizo caca?' [Who pooped?] | 'Ma_co'/Marco/[Marco] — accusing his brother to avoid suspicions that he did it).

The attitudinal function appeared with interventions involving monosyllabic rejection/acceptance ('sí' [yes], 'no' [no]), which cannot be questioned as they can in the informative function. In 2;1 (5), the adult suggests: 'Vení, juguemos a la pelota' (Come here, let's play with the ball), and B responds: 'Sí' (Yes). The affirmative word provides no information (except for the fact that all expressions somehow provide information) but instead merely reveals B's willingness. In 2;1 (5) the adult asks B if it could be their turn ('Ahora yo. ¿Puedo yo?' [Now me. May I?]), and B responds: 'No, yo' (No, me). B has provided no information other than his will with regard to the idea that it can be the adult's turn. This is not an expressive function, if by that we mean the expression of feelings centred on the speaker; B simply lets his opinion on the adult's proposal be known.

The phatic function was shown in conventional formulas in the language ('perdón' [sorry/excuse me], 'por favor' [please]) which were used easily from the beginning of this period. When $\mathrm{B}$ received something from another person, he invariably said 'Iaia'/gracias/(Thank you), but he never did if he received help or in response to different actions from which he benefitted. He also participated in certain games or conversations without being truly involved, simply intervening with words that were sometimes nothing other than crutches to hold his place within the exchanges. For example, despite being able to use 'no' (no) appropriately, he sometimes used it without meaningful content in order to keep the channel open. In 1;8 (3), when asked about his crib ('¿Dónde está tu cuna?' [Where is your crib?]), he responded 'No' (No) distractedly as he was involved in something else. Somewhat later in the same session, when questioned whether he preferred '¿Esto o esto?' (This one or this one?), he once again answered with 'No' (No). In 2;3 (19), he was asked to put on a hat, and one in particular he was holding to encourage the action: 'Dame ese gorro' (Give me that hat). B responded, without dropping his own and without actually doing it: 'Sí, doy' (Yes, I give), but as if he had never really been part of the conversation. It is as if he had realized that it was his turn to say something, and he said it, in this case something appropriate, but without being truly involved.

The interventions with the echo function were reflected in all kinds of repetitions of the ending of the adult's utterances. In 1;10 (9), while acting like he was touching fire in a picture book, B could not name it despite the questions ('¿Qué es eso? ¿Cómo se llama?' [What is that? What is it called?]). Instead of answering, he put his hand on the drawing and retracted it with the exclamation '¡Ay!' (Ouch!) (as if signalling that that burns). When then asked ¿¿Qué hizo el 
fuego?' [What did the fire do?], B just repeated: '_eu_o'/fuego/(fire), with the diphthong of 'fuego' (fire) inverted and the consonants omitted. Somewhat later, the adult told him: 'El señor [del cuento] se inventó un helicóptero' (The man [from the story] invented a helicopter), from which B copied: 'O-có_te_o'/ helicóptero/(helicopter). In 1;11 (1), the child and the adult were playing with a microphone. Adult: ‘¿Querés que lo apague?' (Do you want me to turn it off?), and B, determined to do it himself, said: '_pa_e'/apague/(turn off). In 2;1 (28), when fighting over a doll, he blurted out: '¡Mi jugador, Bruno!' (My player, Bruno!), and he repeated: '_u_a_or'/jugador/(player). In 2;2 (29), when comparing a series of plastic letters scattered around the floor, it was suggested that he pair up similar ones: 'Así, juntas' (Like this, together) and B said: '-ntas' (ether). As the research proceeded, B began to copy longer and more complex phrases. In 2;5 (1), the adult said: 'Me parece que no' (I don't think so), and he repeated: '-ece que no' (don't think so). In the same session, when told: 'Es del mismo color' (It is the same colour), B repeated, with perfect modulation: 'Es del mismo color' (It is the same colour).

The echo function also translated into gestures. In 1;9 (17) B was successively touching a book and using the pointing gesture towards the pictures that the interlocutor had just touched, a kind of completion of the other's action. These gestures provided no information, nor were they expressive; they were not trying to do anything or ask for anything. Instead, they were simply an echo-like repetition of the gestures seen, first-person recognition of what the other shown to by naming and pointing.

\section{Discussion}

Even though we have found a preference for the oral modality, the correlation between the total frequencies of gestures and vocalizations enables us to interpret that the behaviours in both modalities remain proportionate and that the gradual increase in oral signs did not come at the expense of gestures. In his predisposition to interact, the child used both resources, with a clear preference for orality, yet without neglecting the potential offered by gestures, and with a relatively constant difference between these two modalities.

In terms of vocalizations, the increase in word vocalizations and the existence of unintelligible vocalizations lead us to estimate that the growth in vocabulary (the presumable and normal inclusion of type-word which are not tallied in this study) and the increase in the use of token-words (increase in loquacity) do not apparently affect the frequency of poorly modulated signs. It can reasonably be assumed that at this point, the child will continue to test out groups of phonemes and words whose form he has not yet mastered.

The fact that the two-word period is a phase of cognitive transition ridden with frustrated trials and attempts is also confirmed by the fact that the dubious and other functions together are ranked immediately below the function with the highest frequency, the informative function. The fact that the frequency of these interventions is so close to the frequency of clear communicative functions 
suggests that in this period the child's semiotic production is still too immature, insufficient or imprecise to capture the mental states that the subject wishes to share with others.

The correlations between the informative/attitudinal functions and functional words enable us to venture a guess that on the one hand, the informative function can be performed with the subject's responses to questions from the interlocutor, while on the other, the same functional elements are used to provide information and to express the subject's stance towards certain suggestions. 'No' and 'yes' are both informative (in cases like ‘Este juguete vuela? [Does this toy fly?] 'No' [No]) and communicators of rejection/acceptance ('¿Querés pizza?' [Do you want pizza?] | 'No' [No]).

The qualitative analysis enabled us to further explore the cognitive-functional features through the specific uses of the signs. The declarative and informative functions, split off from Jakobson's referential function, are justified in their diverse uses and in the greater complexity of the latter in terms of cognitive processing, which means joining two signs with different semantic contents. However, it does not seem accurate to separate both functions based on the fact that one corresponds to utterances with a single element while the other to compositions with two or more signs. Ultimately, the cognitive difference should not merely translate into the number of signs expressed.

In light of the examples, the conative function continues an early presemantic routine in baby-adult interactions or proto-conversations (Trevarthen, 1980). Just like them, the expressive action, either vocal or gestural, involves both interlocutors, with the addition that since the appearance of the explicit sign, it provides the possibility for the exchanges to entail requests and demands. Thus, it is possible to trace a certain continuity between proto-conversations, proto-imperative uses of gesture and the uni- and bimodal conative back-andforth, which is present here and broadly recognized in adult classifications.

The expressive function, the first to be manifested ontogenetically (because biology equips newborns with resources like crying and facial expressions), is reconverted into the world of signs without leaving behind other, more primitive options. In the early use of words, it becomes prominent in non-lexical vocalizations only in certain situations; in others, just like in adults, the expression may be an interjection whose volume, tone, prosody or context enables one to understand that it is expressing surprise, fear or happiness. Therefore, the expressive function, the primary and most spontaneous form of signifying, progresses towards language with all the other signs, but it never entirely gives up its primary behavioural patterns.

Therefore, our discrimination of an attitudinal function distinct from the expressive function seems justified. The child's attitude towards different alternatives suggested by his interlocutor cannot be confused with the spontaneous action of a mood (Bühler, 1934). If the rejection/acceptance of stimuli is a behaviour that is present from the very beginning, here the use of signs places this attitude in a higher sphere of semantic specialization. The examples reveal 
that attitudinal communication apparently cannot be reduced to other communicative functions.

With regard to the phatic function, we have seen how B used signs anchored in a given context ('Iaia'/gracias/[Thank you]) or devoid of meaning ('No' [No]). In the former, B revealed that he was in a phase in which the use of sign was ritualized, without understanding its entire range of applications. With regard to the latter, which is clearly inadequate, its use only seems interpretable as an exercise to save his place in the conversation. B knew how to use 'no', but he was also capable of emptying it of meaning and using it in an idiosyncratic way. Once again, the device of these exchanges is that of proto-conversations: the dialogues at this time do not conceal that pre-semantic archaic structure. The 'no', just like the crutches devoid of meaning ('éste' [this], 'acá' [here], etc.), seems like a remnant of those first phatic exchanges.

The echo function, in turn, seems at least partly governed by the goal of incorporating words. This concurs with the fact that primarily new (and final) words from the adult's diction are repeated. The echo function seems to disappear from the competent speaker later (perhaps except for in second-language learning), which is perhaps why it has not been included in the categorizations of adult language. At the same time, this function is not exclusive to words, but unlike with words, the echo gesture does not necessarily aim to incorporate new signs. In any case, in example 1;9 (17), when B touched the pictures in the book that the adult interlocutor had previously touched and then named (an interactive structured repeated on other occasions), the echo function seemed to have the goal of eliciting cognitive processes of exploration. In the morphological sphere, some similarities with the so-called magnet effect (Rodríguez, 2007), which consists of arousing the child's interest in taking an object he or she is shown, could be highlighted. However, unlike the canonical case of the magnet effect (child raising his/her hands to grab the object offered by ostension), here the object matters less than the game itself (touching what the other has touched simply because the other has touched it). This is more a playful strategy which implies (a) going where the other has gone and (b) ensuring turn-taking in the interventions (survival of the primary proto-conversational pattern), never touching before the interlocutor does. While the magnet effect seems to rigorously imply a requesting action (conative function), in the sequence described here it is a back-and-forth pattern governed by succession and taking care to reproduce the adult's action playfully.

\section{Conclusions}

The cooperation of the two modalities (oral and gestural), as shown in Table 2, reveals how the purpose of speech-language, as a relatively autonomous system of meaning and communication, becomes consolidated by first exploiting the different resources and channels of interaction with the adult. In this way, the results of our study are aligned with other research on early developmental semiotics (Butcher \& Goldin-Meadow, 1993; Zlatev \& Andrén, 2009) and 
support the theory of a semantic processing mechanism common to both gestures and words (McNeill, 1992, 2005).

With regard to the limitations of this study, it is clear that the common limitations of the case-study methodology were identified here as well: it is particularist, descriptive and heuristic (Merriam, 1998). As is common knowledge, this means that it is not appropriate to generalize the results of our empirical study. Longitudinal observation does not test hypotheses and is never free of the risk of reflecting biases in personal thinking, individual differences in maturation and the uncontrolled influence of outside variables, 'although it does provide [...] scientific rigour par excellence (López Ornat, 1994, p. XVII) because any attempt at an explanation has to be able to account for the evidence collected. The further data collection currently underway will enable us to test the soundness of our classificatory system. On the other hand, these limitations should be weighed considering that 7.5 hours of multimodal communication were recorded, with a total of 5,105 simple and composite vocal and gestural interventions for a period that has been studied relatively little, within which categories were applied for functions that have never been studied before.

The study has provided evidence of the behaviour of the communicative uses in the two-word period, equally examining communications with oral signs (vocalization, word) and gestural signs. To optimize the exploration of this period, a crucial juncture within the ontogenetic development of communicative skills, an observational code was developed which bore in mind the previous classifications but was adapted to our objectives. It became obvious that new categories had to be added to cover communicative functions which were not recognized in the specialized literature. A great deal has been written on the ontogenetic development of the types of signs, but much less about the shifting vicissitudes in the communicative functions. The code also addresses an extraordinarily important deficit in the practical sphere, namely the lack of clearly detailed nominal and operational definitions. The lack of an explicit formulation, which is rectified in this study, provides future research with the option of a clear basis for deciding whether a particular intervention by the child pragmatically corresponds to a given communicative function, as well as the possibility of reevaluating this category and redefining it, if needed, an alternative which is only possible thanks to the transparency we sought.

The classical functions of language (Jakobson, 1960), which were extended over the entire communicative spectrum in our study, are generally within the repertoire of uses that $\mathrm{B}$ exhibited since the beginning of the period studied, with exceptions for the poetic, metalinguistic and executive functions. The split of the referential function into declarative and informative — which we believe is justified - and the inclusion of the attitudinal and echo functions are contributions which do justice to a decisive period in the language acquisition process. The distinction between the declarative/informative function is important because it honours the differences between naming and saying, between organizing the world into word categories and making predications (an Aristotelian discernment supported by Coseriu in a twentieth century which is overly centred 
on the descriptive-propositional aspects of language and used to overlook the essential role of words before their insertion into larger structures; Coseriu, 2015). The split is doubly relevant when the goal is to explore the ontogenetic development of the child's expression, bearing in mind that there is a notable cognitive leap between allusion and proposition.

The attitudinal function has been shown to be a different cognitive category from the informative function, since it reports on a subjective predisposition, and from the expressive function, in that the subjectivity at stake is no longer essentially emotional but instead regarding propositional exchanges. Thus, the attitudinal function brings a new dimension to both the classical and more recent studies on linguistics and developmental psychology (Bruner, 1981; Halliday, 1975; Murillo \& Belinchón, 2013).

Discerning the echo function was also shown to be pertinent; it consists of repetition of something that the other expressed, and it is important to have distinguished it from the phatic function (since the former has the intention not of preserving the channel but of integrating a new element into the lexical repertoire). At some point, this function fits within the logic of the kind of reiteration in working memory that corresponds to the subsystem of the phonological loop (Baddeley, 2003), which repeats verbal inputs to extend the fleeting life of these stimuli. The difference is that here the exercise seeks not to extend the time during which a word is available to other cognitive processes but to add it to the child's mental lexicon. Therefore, one objective of the echo function is long-term memory. Inasmuch as the phonological loop also seems to be related to acquisition of the system of oral language signs (Baddeley, Gathercole, \& Papagno, 1998), the visible utility of the echo function and the silent processing which happens regularly in the working memory may be seen as allies in the goal of gestating the language in the mind. Therefore, the echo function is an important category for theories of language acquisition which view it as a gradual, non-linear ontogenetic process (López Ornat et al., 1994) entailing a testing and repetition component.

In short, the behaviour of the vocalizations and gestures enables us to confirm a co-dependence in the development of expressions, and counter to expectations, it does not enable us to think that the increase in the use of signs in the oral modality happens at the expense of the frequency of gestures. The unimodality of verbal expressions thus can be seen as a derivation from the original multimodality. The increasing autonomy of the speech does not erase the prelinguistic origin of the communicative functions and the essentially social mission which lies at the heart of human subjectivity. Linguistic communication is declarative, informative, conative, expressive, phatic, attitudinal and echoing (plus other functions which appear later), but strictly speaking, vocalizations and gestures would have already explored all of these possibilities by the time the word becomes grammatical and conquers an increasingly prominent space. 


\section{Las funciones comunicativas durante la etapa pregramatical: un estudio de caso}

Las funciones comunicativas con las que se emplea el lenguaje han sido ampliamente abordadas, discriminadas y discutidas (Jakobson, 1960; KerbratOrecchioni, 1986). Existe, sin embargo, un relativo soslayo del estudio de las funciones comunicativas en el período pregramatical. Cuando se las investiga, los abordajes adolecen de cierta parcialidad, enfocando algún tipo de signos en desmedro de otros (gestos, vocalizaciones, palabras, composiciones de gestopalabra). En un trabajo destacado, Crais, Douglas, y Campbell (2004) analizaron las funciones del gesto deíctico y el representacional desde su aparición hasta los 24 meses, aportando valiosa información acerca de los recursos semióticos del niño. Otros trabajos optaron por limitarse a ciertas funciones específicas, clásicamente las funciones protoimperativa y protodeclarativa, sin contemplar otros usos del signo (Cochet \& Vauclair, 2010; Romero Andonegi, Etxebarria Lejarreta, de Pablo Delgado, \& Romero Andonegi, 2017). Otros, al contrario, se extendieron más allá de las fronteras de lo estrictamente comunicativo, abarcando funciones cognitivas no-intersubjetivas (Delgado, Gómez, \& Sarriá, 2010; Dupertuis \& Moro, 2016; Español, 2006); estos estudios comprenden al gesto autodirigido, al que se asigna un importante rol como herramienta del pensamiento y del desarrollo semiótico, pero cuyo valor significativo no implica inmediatamente que se trate de un signo comunicativo. Si se considera que el proceso de comunicación reparte los roles de emisor y receptor entre dos sujetos distintos (Rodríguez, 2017; Romero Andonegi et al., 2017), es relevante mantener la distinción entre procesos de autorregulación y procesos comunicativos. Con todo, el gesto de pointing en sí mismo ha revelado recientemente usos más complejos que los anteriormente identificados (Tomasello, Carpenter, \& Liszkowski, 2007; Rodríguez, 2009). De cualquier forma y al margen de las controversias, las consideraciones anteriores, sumadas al avance en general de la investigación sobre infancia temprana y al creciente interés por los aspectos pragmáticos de la comunicación, sugieren que las funciones comunicativas son un factor que promueve en el niño el desarrollo de las relaciones interpersonales. Ello no obstante, son todavía un campo subexplorado.

Junto con el relativo soslayo de las investigación empírica sobre las funciones comunicativas en la infancia temprana, los estudios sobre el desarrollo de habilidades semióticas en la niñez suelen concentrarse en dos períodos fundamentales: por un lado, en el período holofrástico (cuando el niño es capaz de producir sus primeras emisiones de signos verbales únicos, pero al mismo tiempo combinando estos signos verbales con signos de la modalidad gestual, dando 
lugar a las primeras estructuras comunicativas compuestas); por otro, en el período de las primicias gramaticales (cuando es evidente una cierta pericia para acomodar las verbalizaciones a las reglas de la propia lengua). Un período intermedio, el denominado período de dos palabras (yuxtaposición de elementos del léxico), reviste sin embargo máxima importancia, dado que en él se produce el pasaje de composiciones agramaticales a gramaticales. Este período ha sido escasamente abordado, fuera de ciertos meritorios esfuerzos concentrados en alguna habilidad semiótica particular (el gesto: Andrén, 2010; gesto y palabra: Zlatev \& Andrén, 2009). El abordaje multimodal está todavía en deuda con el desarrollo de la semiosis infantil. Sólo recientemente, Rodríguez y Español (2016) consideraron todas las opciones sígnicas de las modalidades oral y gestual: gestos, vocalizaciones de palabra y no-palabra, composiciones de una modalidad (gesto-gesto, vocalización-vocalización) o dos modalidades (gesto-vocalización). La presente investigación quiere suplir este triple déficit - cronológico, temático y de perspectiva - abordando el estudio de las funciones de las comunicaciones del niño desde el conjunto de opciones sígnicas de las modalidades oral y gestual presentes en el período de dos palabras.

\section{Las funciones comunicativas antes de la gramática}

Hacia el comienzo del segundo año de vida el niño gesticula y verbaliza al mismo tiempo o en secuencias integradas temporal y semánticamente. Se ha reconocido que esas yuxtaposiciones sígnicas de dos modalidades emisivas diferentes constituyen las primicias de la significación compuesta (Butcher \& Goldin-Meadow, 1993). Así, el proceso general de adquisición del lenguaje (tomando al lenguaje como una estructura léxica gramaticalizada) atraviesa por momentos pre-gramaticales donde gesto y palabra se apuntalan recíprocamente antes de que el sujeto sea capaz de encadenar sólo signos lingüísticos. La detección de estos usos combinados fue un importante aporte a la exploración de los estudios del desarrollo semiótico, pero a los efectos de una comprensión más amplia del mundo semiótico infantil debe aún incorporarse, a la configuración formal de los patrones comunicativos, el estudio de las funciones con que el signo se utiliza en el afán de interactuar.

Es un lugar común renegar de la utilidad de distinguir y enumerar funciones comunicativas (o, en principio, funciones del lenguaje, ya que es de esta cantera de donde se toman tradicionalmente las categorías para abordar el desarrollo de la comunicación, procedimiento que, por cierto, limita profundamente la investigación para estudiar el desarrollo del lenguaje). El argumento clásico es que las funciones del lenguaje no son excluyentes unas de otras y que toda emisión implica sin remedio más de una función, por lo que, de esta suerte, las categorías conllevan siempre algún solapamiento. Ello no puede, sin embargo, servir de objeción para el hecho aceptado de que el niño aprende su lengua materna para vincularse con los otros, y que sin esa motivación pragmática sería difícil explicar el interés por un aprendizaje que demanda tiempo y esfuerzo. Si 
se asume que el lenguaje sirve a la naturaleza o condición social del ser humano, no cabe plantear que los problemas de categorización sean suficiente obstáculo para estudiar a fondo las funciones comunicativas. En otros términos, no puede admitirse que dificultades en la operacionalización puedan jaquear la epistemología del objeto de estudio.

Al problema de que las categorías usadas para investigar la comunicación lingüística sean apropiadas para investigar también la comunicación sin más, un territorio donde la palabra se confunde con signos desemejantes, se añade el de que las funciones comunicativas y lingüísticas pueden no ser las mismas en los sujetos adultos, con capacidad gramatical, y en los niños pequeños que recién están haciendo acopio de sus primeras palabras. Es por ello necesario que el código de observación se acomode a su objeto de estudio y al período por estudiar.

Los sistemas de categorías de observación para evaluar funciones comunicativas llevan normalmente, por el lado psicológico, a Bruner y a Bühler, por el lado lingüístico, a Jakobson y a Halliday. Bühler (1934), pionero de la psicología del desarrollo, estableció una tríada de funciones básicas: expresiva, apelativa y representativa, centradas respectivamente en el protagonismo de la primera, la segunda y la tercera personas gramaticales (en la emisión subjetiva, en la búsqueda de un receptor y en la referencia a un estado de cosas concebido como referencia). Este modelo resultaba sin embargo limitado y dejaba por fuera otras variantes del empleo del signo. En Jakobson (1960) se encuentra un esquema enriquecido con la función fática (en la que el contenido del mensaje carece de relevancia y sobre todo importa la preservación del vínculo/canal de interacción), la función poética (centrada en el cuidado de la forma) y la función metalingüística (donde el desdoblamiento de la comunicación en dos niveles, lenguaje-objeto y metalenguaje, ilustra cómo un enunciado puede ser motivo de otro para el cual opera como referente). Por su parte, Austin (1962) completaría este elenco destacando un punto descuidado por todas las investigaciones anteriores, a saber la idea de que el lenguaje es no tan sólo una herramienta para la expresión de un contenido sino al mismo tiempo un medio de realización de acciones (función ejecutiva en la que, por ejemplo, al decir 'yo prometo' indefectiblemente estaré prometiendo). Bruner (1981) por su parte, atento observador de la semiosis infantil, reestructuró el campo planteando tres orientaciones funcionales, comprensivas a su vez de otras funciones subalternas: (1) regulación de conducta (requerimiento de objetos, de acciones o reclamos); (2) atención conjunta (comentario, requerimiento de información); (3) interacción social (gesticulación representacional, búsqueda de atención y juegos sociales). Su esquema disuelve la pauta agencialidad-mutualidad-referencialidad de Bühler, sustituyéndola por una idea de dualidad omnipresente bajo los designios de exigir, informar y compartir. También atento a las vicisitudes del desarrollo, Halliday (1975) interpretó que existen siete funciones irreductibles en la comunicación del niño: instrumental (comprometida con las necesidades del emisor), regulatoria (de la conducta de otros), interaccional (destinada al contacto desinteresado con los otros), personal (equivalente a la función expresiva), heurística (al servicio de obtener mayor conocimiento del mundo inmediato), imaginativa (destinada a creaciones 
ficcionales) y representacional (con afán de hacer saber). Este conjunto se divide entre el grupo de las funciones que ayudan al niño en la satisfacción de sus necesidades materiales y sociales más urgentes (primeras cuatro) y en el mutuo entendimiento acerca del mundo (las restantes). En una segunda fase de desarrollo se suman las funciones matética (el lenguaje como herramienta cognitiva) y pragmática (uso relativo a la regulación del propio comportamiento). En una tercera instancia, Halliday añade las que denomina macrofunciones del lenguaje: ideacional, interpersonal y textual (que implica la inserción de las unidades verbales en contextos cada vez más complejos).

Es evidente que las distintas categorizaciones presentan recubrimientos (cfr. Tabla 1), pero también particularidades. El problema de escoger cuál de ellas adoptar como parámetro de la labor de observación no puede despejarse en razón de evaluar sus méritos intrínsecos (que todas tienen) sino desde el objetivo de cada investigación concreta. Por ello, las clasificaciones de Bühler y Bruner (ambas, en esencia, de tres tipos cada una) parecen 'en falta', o funcionalizar 'de menos' las utilidades que el niño pequeño puede extraer de su elenco completo de recursos comunicativos. Al contrario, Halliday distingue tipos que

Tabla 1. Comparación entre otros sistemas de categorías mencionados y el de esta investigación.

\begin{tabular}{|c|c|c|c|c|}
\hline BÜHLER & BRUNER & HALLIDAY & $\begin{array}{l}\text { JAKOBSON } \\
\text { AUSTIN }\end{array}$ & $\begin{array}{c}\text { ESTA } \\
\text { INVESTIGACIÓN }\end{array}$ \\
\hline \multirow[t]{3}{*}{ representativa } & atención conjunta & representacional & referencial & declarativa $*$ \\
\hline & & heurística & & \multirow{2}{*}{ informativa * } \\
\hline & & imaginativa & & \\
\hline \multirow[t]{2}{*}{ apelativa } & $\begin{array}{c}\text { interaccional } \\
\text { social }\end{array}$ & interaccional & \multirow[t]{2}{*}{ conativa } & \multirow[t]{2}{*}{ conativa } \\
\hline & $\begin{array}{l}\text { regulación } \\
\text { conducta }\end{array}$ & regulatoria & & \\
\hline \multirow[t]{2}{*}{ expresiva } & interaccional & instrumental & \multirow[t]{2}{*}{ expresiva } & expresiva \\
\hline & $\begin{array}{r}\text { regulación } \\
\text { conducta }\end{array}$ & personal & & actitudinal * \\
\hline \multirow[t]{5}{*}{ - } & \multirow[t]{5}{*}{ - } & \multirow[t]{5}{*}{ - } & fática & fática \\
\hline & & & - & eco $*$ \\
\hline & & & poética & $?$ \\
\hline & & & metalingüística & $?$ \\
\hline & & & ejecutiva & $?$ \\
\hline
\end{tabular}

Nota: $(*)$ categorías novedosas/reformuladas en esta investigación. (?) categorías improbables en este período. Se omiten la función dudosa y la función-otro, categorías metodológicas. 
entendemos podrían condensarse en una sola clase (por ejemplo, la instrumental y la regulatoria) y, en relación con sus macrofunciones, se proyectan por encima de los actos comunicativos, aquello precisamente que nuestra investigación pretende relevar. La clasificación de Jakobson (con el aporte de Austin relativo a la función ejecutiva) parece más rica en su oferta de opciones pero es, sin embargo, una categorización pensada para el hablante maduro en posesión de competencias por encima de la semiosis del niño (la función metalingüística y la poética presuponen, ambas, la capacidad de arquear o flexionar la lengua sobre sí, en el primero de los casos para hablar acerca de ella, en el segundo para embellecer el vehículo formal). Con todo, era la clasificación más conveniente como punto de partida: en términos prácticos, por ser la más difundida y permitir un diálogo psicología-lingüística; en términos teóricos, por desplegar una paleta de funciones más sugerentemente excluyentes (aun si las grabaciones y los primeros esfuerzos de decodificación revelaron deficiencias y llevaron a efectuar ajustes - detallados en el código de observación, cfr. más abajo).

En el territorio particular de los estudios semióticos durante la infancia temprana suele existir todavía hoy cierta pregnancia de la clasificación de Bates, Camaioni, y Volterra (1975), que distingue entre dos usos básicos del gesto, declarativo e imperativo (por ejemplo, Esteve-Gibert \& Prieto, 2013; Murillo \& Belinchón, 2013; Romero Andonegi et al., 2017). Algunos desarrollos innovadores, como las utilidades del gesto de pointing antes destacadas (Tomasello et al., 2007) o los gestos protointerrogativos (Rodríguez, 2009) no han sido integradas todavía a una categorización sistematizada. Un comentario aparte merece la codificación de Sarriá Sánchez (1991), que propone una herramienta multidimensional para el período preverbal prolija y exhaustiva, pero que al tomar como unidad común de clasificación la categoría natural de 'acto comunicativo intencional', no distingue entre acciones comunicativas y gestos, volviendo homogéneos dos estadios diferentes del proceso de adquisición de habilidades semióticas. En efecto, allí está contemplado como gesto el giving (dar), el cual, si bien constituye un momento esencial en el desarrollo semiótico, antecede a la condición de signo sensu stricto. Para la comunidad de expertos el acto de dar se encuentra en una zona nebulosa entre las categorías de acción y gesto. Las acciones pueden tener fines comunicativos, por lo que es posible tomarlas por gestos; sin embargo, algunos autores diferencian unas y otros a partir de la hipótesis vygotyskiana de que los primeros gestos del niño devienen directamente de una estructura comunicativa primitiva - comunicación incidental creada por las acciones del niño y su interpretación por el adulto - mediante cambios en la forma y en la función de la acción directa (Andrén, 2010; Clark, 1978; Rivière \& Español, 2003; Rivière \& Sotillo, 1999). Bajo esta hipótesis, Español (2004) describió detalladamente, como transformación de la acción de dar, la génesis del gesto de mostrar (para el caso puntual del gesto en que el niño, objeto en mano, lo presenta a la mirada del adulto, moviéndolo sutilmente y sin llegar a darlo ni esperar que sea tomado), dando cuenta de las formas intermedias que caracterizan al proceso. El dar, en este marco teórico, es la acción (sin duda comunicativa) de la 
cual deviene el gesto de mostrar (para una visión distinta, Rodríguez, MorenoNúñez, Basilio, \& Sosa, 2015).

Luego de revisar todas estas variantes, nos vimos llevados a forjar un código de observación sui generis que, nutrido con las categorías de estudios anteriores, las reexaminara para acomodarlas a nuestro período y objetivos (aportando las definiciones nominales y operacionales que suelen echarse en falta en investigaciones similares).

La investigación que presentamos persigue el objetivo general de realizar una descripción exhaustiva de las funciones comunicativas de gesto y de vocalización durante el período de dos palabras (19-27 meses). Este período, que ostentó otrora la dignidad de ser aquel en el que el niño, por primera vez, podía ligar con la expresión dos signos diferentes, debió ulteriormente resignarla cuando se advirtió que en el período precedente, llamado holofrástico, se verifica la presencia de composiciones de gestopalabra, lo que significa que el enlace entre dos signos comunicativos no debe aguardar al encadenamiento de dos términos verbales (Butcher \& Goldin-Meadow, 1993). Sin embargo, es por su calidad de enlace entre composiciones agramaticales y la aparición de las primeras estructuras con morfosintaxis que el período de dos palabras ofrece un tipo distinto de interés. Es su cronología intermedia lo que le confiere el atractivo para investigar el pasaje entre ambos niveles comunicativos, ubicándose de esta manera como un territorio especialmente fértil para la psicología del desarrollo en la infancia temprana (Rodríguez, 2017). En beneficio de extender la exploración hasta el momento en que comienzan los estudios sistemáticos del desarrollo del lenguaje (30 meses — Andrén, 2010), las observaciones de nuestro estudio se prolongaron a los dos meses siguientes, para los que hay asimismo escasa información, abarcando entonces de los 19 a los 29 meses de edad.

Aunque un estudio de este tipo no posee hipótesis en sentido estricto (Hernández Sampieri, Fernández Collado, \& Baptista Lucio, 2006), partimos del supuesto de que la multimodalidad comunicativa es la matriz fundamental del desarrollo semiótico temprano, su presencia se verifica en todo el período abordado y, por tanto, las funciones comunicativas de esta edad reflejan la fina cooperación entre los registros oral y gestual.

\section{Método}

En este apartado se desarrollará el apartado metodológico donde, primeramente, se describirá el tipo de estudio realizado, más tarde se expondrán los participantes, y se finalizará explicando los materiales y el procedimiento empleado

\section{Tipo de estudio}

Se realizó un estudio evolutivo longitudinal de caso único. Este tipo de estudio posee una larga tradición de antecedentes (Brown, 1973; Hernández Pina, 1984; 
López Ornat, Fernández, Gallo, \& Mariscal, 1994) y se halla justificado, metodológicamente, porque permite evitar 'los problemas de interpretación que provocan los procedimientos experimentales al cortar, entre dos puntos, el continuum evolutivo' (López Ornat, 1994, p. XVI). En este estudio se utilizó el corpus observacional de las interacciones adulto-niño y el sistema de categorías para tipos de signos registrado en Rodríguez y Español (2016).

\section{Participantes}

Una díada adulto-niño. Bruno (en adelante B) es un niño argentino de la ciudad de Buenos Aires, nacido en un hogar de clase media, con un hermano casi tres años mayor, padres profesionales, familia monolingüe. No es niño prematuro ni ha sido diagnosticado con trastorno de desarrollo. Hijo menor del primer autor. Para esta decisión metodológica existen importantes precedentes (Forrester, 2010; Hernández Pina, 1984; López Ornat, Fernández, Gallo, \& Mariscal, 1994; Piaget, 1937/1988) y una clara justificación teórica: la cercanía cotidiana asegura poder registrar los intercambios garantizando la decodificación de la media-lengua del niño, los elementos idiolectales que pudiera poseer, y las características contextuales tácitas que condicionan la comprensión de la conducta y la expresión situacionales. La edad del niño en la primera sesión - siguiendo la nomenclatura piagetiana año;mes (día) - fue 1;7 (13); en la última, 2;5 (1).

\section{Materiales y procedimiento}

Se registraron 15 sesiones de interacciones cotidianas de la díada niño-adulto, cada una de 30 minutos de duración, cada 20 días durante el período comprendido entre los 19 y los 29 meses. En las sesiones se emplearon distintos juguetes (autos, pelotas, juegos de cubos, de insertar, etc.), libros de cuentos y objetos cotidianos de un hogar de clase media, variando según las ocasiones y los escenarios (cuarto del niño, living-comedor, cocina, etc.). En todos los casos, el adulto interactuante (padre, madre y niñera, alternando las sesiones) iniciaba los intercambios con propuestas de actividades (lectura de cuento, juego con autitos, etc.) libradas después a la espontaneidad del niño, siempre en un marco de interacción libre para que este decidiera la temática y las formas (por ejemplo, en cierta oportunidad su interés se concentró espontáneamente en un conjunto de letras de colores imantadas sobre la heladera). Por regla, la sesión transcurría con el adulto interlocutor y el niño sentados en el suelo frente a frente a una distancia aproximada de $1-1 \frac{1}{2}$ metros, cuidando que los dos cuerpos se encontraran siempre dentro del cuadro de imagen de la cámara. La alternancia de los interlocutores adultos buscó anular la posibilidad de que hubiera algún sesgo en el estilo de los intercambios por causa del partenaire. Todas las sesiones fueron grabadas por el padre-investigador o la madre del niño, atentos a regular el zoom cuando el niño ocasionalmente se incorporara o realizara algún desplazamiento. Se utilizó una cámara Sony DCRDVD505, de uso habitual en el medio familiar del niño (por lo que no fue necesario realizar actividades de adaptación). 
Se asumieron como comunicaciones las expresiones del niño intencionalmente dirigidas al interlocutor y se utilizó el sistema de categorías para tipos de signos (gestos, vocalizaciones no-verbales, palabra, composiciones uniy bimodales) recogido en Rodríguez y Español (2016). Las vocalizaciones incluyen una categoría de modulaciones ininteligibles, casos en los que, por la dicción deficitaria propia de esta edad, era imposible decidir exactamente a cuál de las categorías debía asignarse la emisión (si acaso alguna). A fin de analizar las funciones comunicativas con que fueron usados los tipos de signos, se confeccionó un código de observación para las mismas generado mediante el Método Comparativo Constante (Strauss \& Corbin, 1998). El sistema definitivo de categorías para funciones comunicativas (cfr. Tabla 1) se aplicó a las categorías semióticas reconocidas y se contabilizaron las frecuencias de cada función para el total de las intervenciones comunicativas del niño. No se emplearon programas informáticos para la codificación. La misma involucró a dos codificadores (los autores de este trabajo), que primero operaron de manera independiente y luego discutieron los casos en desacuerdo. Se cumplieron los siguientes pasos: (a) cada sesión fue revisada por los dos codificadores de forma independiente; (b) aquellos eventos en los que hubo desacuerdo fueron discutidos hasta lograr consenso; (c) los eventos sin acuerdo fueron eliminados de la contabilización. Este procedimiento es consistente con los usados en estudios de interacción social (Español, Bordoni, Martínez, Camarasa, \& Carretero, 2015; Forster \& Iacono, 2013; Jonsson et al., 2001; Martínez, Español, \& Pérez, 2018). Para el análisis de datos se utilizó el programa estadístico informático SPSS 20.0.1. Dado el nivel de medición de las variables, se calculó el coeficiente de asociación de Spearman.

La clasificación adoptada (Rodríguez \& Español, 2016) comprende, además de la dimensión ya destacada por tipos de signos, una segunda dimensión de categorías para contabilizar conjuntamente unidades semióticas de la modalidad oral y la modalidad gestual según su rol semántico genérico. De esta manera, la producción total de gestos y de vocalizaciones resulta organizada en: (a) signos denotativos (descriptivos o referidos a un ente real/virtual); (b) funcionales (con tareas de enlace o modificación sobre el significado de otros signos: signos de enlace, afirmativos y negativos); (c) expresivos (portadores de semántica afectiva, no referidores); (d) dudosos (para signos en los que no era posible establecer en qué categoría, entre dos, debían clasificarse: si la dicción 'o_to' correspondía al adjetivo 'otro' o a cierta modulación, cerrada, de 'auto'); y, finalmente, (e) signos-otros. La categoría 'dudoso' no ha de confundirse con la de 'ininteligibles'; mientras aquella implica ambigüedad, ésta supone imposibilidad de detectar carga semántica en la vocalización. Las categorías genéricas intermodales (a)-(e) agrupan los signos por sus aptitudes significativas básicas: ¿para qué sirven los signos en sí mismos, según su perfil predefinido - denotar, ligar, expresar emociones, etc. - fuera de los usos específicos con que los emisores los emplean en cada caso? El registro de uso (el objetivo de nuestra investigación) no debe equivocarse con las aptitudes significativas 'naturales' de los signos aquí señaladas. 
Es conveniente en este punto realizar ciertas precisiones sobre las transcripciones de la expresión del niño. Se emplea el carácter + para indicar, según los usos, yuxtaposición de signos en composiciones bimodales (por ejemplo, en pointing + 'Acá') o para la indicación de los tipos de componentes en composiciones semejantes (gesto representacional + sustantivo). Las barras inclinadas se utilizan para encerrar el significado de una expresión de la oralidad o la gestualidad que no pudiera eventualmente comprenderse por la transcripción literal ('muto'/mucho/). El guión bajo _ se utiliza para indicar la ausencia de un fonema ('E_te'/este/) y el guión medio para indicar la falta de toda una sílaba ('-yó'/cayó/, 'pe-ta'/pelota/) o incluso más unidades fonemáticas. Las barras verticales separan las intervenciones de los actores de un diálogo (‘¿Este es tuyo?’ | No’).

\section{Código de observación}

Sobre la base de la clasificación de tipos de signos y categorías genéricas indicadas y mediante la iterativa observación del material registrado, nuestra codificación de las funciones comunicativas se fue adaptando a los tipos de signo que el niño efectivamente producía. Se desecharon las categorías que la casuística volvía superfluas para este período, se fundieron otras (funciones de 'petición' y 'pregunta' — López Ornat et al., 1994 - y los gestos protointerrogativos - C. Rodríguez, 2009 - se integraron como función conativa) y se discriminaron otras nuevas. Las principales novedades teóricas de nuestro sistema categorial son las siguientes:

- la función referencial (Jakobson, 1960) fue desdoblada en las funciones declarativa e informativa, abarcando respectivamente los usos alusivonominativo (nombrar un objeto; si se tratara de un gesto, poner de relieve que se lo ha identificado) la primera, y predicativo (decir algo sobre el referente: 'E_te titito'/este chiquitito/, 'E_te rrrrr'/esto (un auto) hace rrrrrrr (al andar)/) la segunda. La distinción estriba en las diferencias cognitivas implicadas y en la importancia del progreso desde la alusión, fruto de un reconocimiento, al ejercicio atributivo (Coseriu, 2015).

- se distinguió una función actitudinal concerniente a casos en los que el sujeto adopta una postura subjetiva respecto de un contenido proposicional, sin ser comunicaciones expresivas (manifestaciones subjetivas motu proprio).

- se distinguió una función eco que contempla aquellas expresiones, fundamentalmente verbalizaciones, repetidas por el niño sin otra aparente predisposición que la de dominar sonidos nuevos, pronunciarlos por primera vez, consolidar el vínculo entre la cadena de fonemas y su contrafaz semántica.

A continuación detallamos las definiciones nominales y operacionales de cada categoría de función, en general ausentes en publicaciones especializadas, motivo de equívocos para entender los resultados. Es necesario volver a indicar que hay casi siempre, entre los tipos de función, algún recubrimiento (Jakobson, 1960). En la codificación se marcó en cada caso la función predominante. Sólo cuando la 
decisión entre dos clases de función resultaba en un forzamiento, se tomaron ambas como principales. Las definiciones operacionales se detallan con la sigla DO.

\section{Declarativa}

Consiste en nombrar o en indicar, según se trate de una vocalización (palabra o no-palabra) o bien de un gesto. No aporta información sobre el referente sino que se limita a mencionarlo o aludirlo deícticamente. DO: abarca todo gesto, vocalización o composición que refiera a un objeto o situación. E.g., 'Auto'; gesto de pointing hacia el referente.

\section{Informativa}

Consiste en atribuir un predicado a un sujeto. La discriminación entre la función declarativa y la informativa descansa en el hecho de que mientras la primera comprende el reconocimiento y la nominación de un objeto o hecho, la segunda es fundamentalmente calificativa. La diferencia entre nombrar — 'esto', 'pelota' y decir algo sobre el 'esto' o la 'pelota' es un indicador sensible de que el niño ha comenzado a componer dos unidades significativas diferentes. DO: abarca todo gesto o vocalización que atribuya a un objeto o situación (a un sujeto gramatical, tácito o expreso) un predicado de algún tipo. E.g., 'Auto lindo'; pointing del auto + 'romp_ó'/se rompió/. Ante cierta pregunta del adulto que requiera datos objetivos ('¿Esto es chiquito?'), se asume que la respuesta ('sí', 'no' u otra) desempeña una función informativa aunque contenga sólo un signo (cuando la predicación implica normalmente al menos dos). Ello sucede porque es en efecto el niño quien, después de haber ligado cognitivamente las dos representaciones decodificadas ('esto' más la representación de pequeñez) juzga sobre la adecuación o no de la pregunta. La información veritativa procede del niño, aun si la construcción oracional la hace el adulto. Esa veritación informa, tanto como cuando la repuesta implica más que un monosílabo asertivo/negativo y suministra un dato que no contuviera la pregunta: ¿¿Dónde va esto?’ |'Acá’; ‘Qué es eso?’ | 'Topa’ (/pelota/).

\section{Conativa}

Consiste en requerir al interlocutor algo de sí o bien del entorno. DO: abarca todo gesto o vocalización con que se pida o se demande alguna acción, palabra, objeto, etc. Ejemplo: 'dame', o gestos deícticos (pointing, showing, request, etc.)

\section{Expresiva}

Consiste en la utilización emocional de los recursos comunicativos. Si bien lo puramente expresivo está representado en el lenguaje por las interjecciones (Jakobson, 1960), ningún enunciado, simple o complejo, de las lenguas naturales puede prescindir de los matices afectivos con que es emitido. La función define sin embargo sólo aquellas comunicaciones donde la emotividad destaca por sobre el mensaje. DO: abarca cualquier manifestación con gestos/vocalizaciones donde el 
factor emocional tenga el mayor protagonismo en términos de intencionalidad. E.g., ‘Posh malo!'/vos malo/, gritado y con gesto enfático de golpe de las manos sobre ambas rodillas.

\section{Actitudinal}

Consiste en la marcación subjetiva de una postura frente a un contenido, en asentir o declinar propuestas, sugerencias, órdenes del interlocutor. Por ejemplo, en este diálogo: ‘¿Querés más sopa?' |'Sopa no', la predisposición ante el ofrecimiento del adulto es negativa. La misma función se cumple con un gesto de rechazo con la mano o la cabeza. No es una comunicación informativa en términos referenciales (verdadera o falsa en el plano judicativo), sino que supone una postura inimpugnable: la negación/asentimiento del sujeto no se hallan supeditados a confirmación del otro, pues carecen de objetividad. DO: cualquier comunicación que exhiba una postura respecto de un contenido ideacional-semántico determinado. Se distingue de la función expresiva en que no es prioritariamente emocional. Cuadra a las expresiones en las que el sujeto se ubica de cierta forma ante un hecho concreto o una solicitación. Nuevamente, como para la función informativa, el enunciado-contenido puede ir por cuenta del adulto ('¿Querés agua?') y la participación del niño limitarse a responder sí/no. La diferencia con esa categoría es en ella el 'sí' o el 'no' se apoyan en un hecho constatable y objetivo (por ende, llegado el caso, la respuesta errónea puede ser rectificada), mientras que aquí se expresa la disposición coyuntural del individuo hacia un hecho o propuesta. En la función actitudinal la comunicación sólo se halla condicionada por la propia autoridad de primera persona.

\section{Fática}

Consiste en el uso de expresiones destinadas a velar por el canal, abrirlo o mantenerlo, establecer la comunicación o interrumpirla. Provee tan sólo información superficial (en el formato de las protoconversaciones sin semántica documentadas desde los dos meses (Trevarthen, 1980). DO: abarca cualquier intercambio comunicativo en el que el contenido del mensaje no sea lo fundamental dentro del marco de la interacción (típicamente, saludos y fórmulas de cortesía retóricas: 'Buenos Días', ‘QQué tal el trabajo?’). 'Gracias' ' ¡Salud!' (al estornudar) serían expresiones esperables en el niño.

\section{Eco}

Consiste en comunicaciones que el niño repite de sus interlocutores sin una aparente utilidad. Puede tratarse de palabras nuevas que se intenta modular e incorporar al léxico mental (esfuerzos que se orientan al dominio del vocabulario), pero también de ensayos de repetición de una palabra conocida. En todos los casos, se repite el segmento final de lo expresado por el interlocutor. Esta 
función no se confunde con la función fática porque, mientras que ésta mantiene transitable el canal comunicativo, la función eco indefectiblemente implica (DO) una repetición total o parcial, inmediata, de expresiones del interlocutor sin sentido en la interacción semántica. E.g., el adulto opina: 'Me parece que no' y el niño replica: '-ece que no'. Para los casos en los que las verbalizaciones-eco se hallaren montadas sobre un tono de interrogación, como si el niño preguntara si está repitiendo bien, se ha consignado en paralelo función eco y función conativa.

\section{Dudosa}

Reúne los casos de emisiones comunicativas de función indecidible (no aquellos en los que los codificadores pudieran no estar de acuerdo sino, al contrario, aquellos en los que acordaban que la comunicación no podía asignarse claramente a una categoría).

\section{Otra}

Abarca los casos de emisión de gesto o vocalización intencionados que no pueden computarse en las demás categorías.

De la categorización clásica de las funciones lingüísticas (Jakobson-Austin) no parecía esperable la presencia de las funciones metalingüística, poética o ejecutiva en el período estudiado. Respecto de la primera, todo lleva a pensar que el niño de escasas palabras, que se comunica de manera fundamentalmente bimodal, carece todavía de una consciencia del lenguaje suficiente como para poder desdoblarlo en los dos planos de uso y de mención al mismo tiempo. Respecto de la segunda, supone estrategias atentas a la forma del mensaje y a la selección y la combinación de signos (Jakobson, 1960). Con un vocabulario todavía muy limitado, parece difícil suponer al niño la capacidad de selección entre dos términos afines, digamos: corcel/caballo, con criterio estético. Respecto de la tercera, dependiente de que ciertos verbos ('prometer', jurar', 'inaugurar' - verbos realizativos) se utilicen en la primera persona del presente indicativo, nada sugería que pudieran hallarse ejemplos de ella en el período estudiado.

\section{Resultados}

Se registró un total de 5,105 intervenciones del niño, con un total de 1,390 gestos y 5,832 vocalizaciones. El número de vocalizaciones excede el de las intervenciones ya que estas podían ser de más de un signo. La Tabla 2 muestra los datos pormenorizados de cada sesión para estas tres variables genéricas y asimismo las frecuencias de tipos de vocalizaciones (vocalizaciones no-palabra, vocalizaciones-palabra e ininteligibles). Por razones de espacio, sólo se incluyen además los datos de aquellas categorías de signos que arrojaron correlaciones 


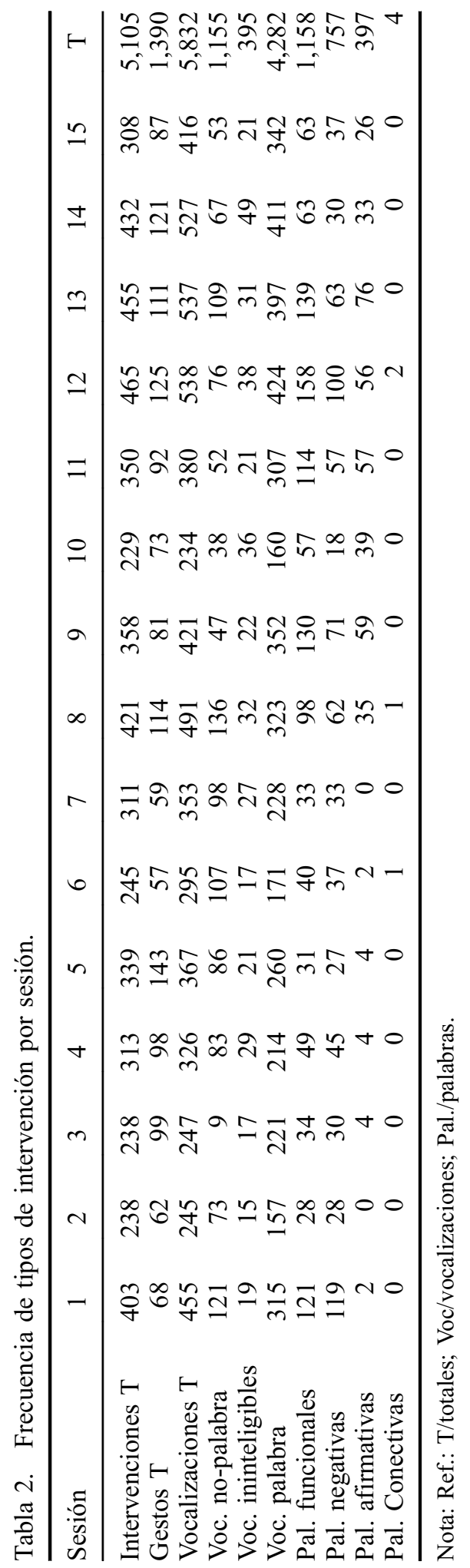


con las funciones comunicativas y los de aquellas que permiten leer contextualmente estas correlaciones.

Como puede observarse en la Tabla 2, la frecuencia de las vocalizaciones totales es superior a la de gestos a lo largo de todo el período. Esto señala una preferencia general por la modalidad oral en las intervenciones de cada una de las sesiones. Se identificó no obstante una correlación positiva entre los gestos y las vocalizaciones totales $\left(r_{s}(14)=.554 ; p<.05\right)$.

La frecuencia de las vocalizaciones no-palabra fue en todo momento inferior a la de vocalizaciones-palabra y la diferencia entre ambas se fue pronunciando con cada sesión de acuerdo con lo esperable en términos de desarrollo. Los ininteligibles, por su parte, se mantuvieron con una frecuencia relativamente constante a lo largo del período, con un incremento ligero a partir de la sesión 8 .

Las frecuencias de las diferentes funciones comunicativas se indican en la Tabla 3.

Todas las funciones distinguidas en el código de observación se mostraron presentes a todo lo largo del período. Algo más de un cuarto de las comunicaciones del niño han cumplido función informativa $(27 \%)$, la cual acusó un incremento sensible a partir de la sesión 8. Junto con ella, la función eco es la que mostró un mayor crecimiento en la frecuencia, por contraste con el resto de funciones, con perfiles irregulares y sin tendencia manifiesta. Durante todo el período, la función fática mostró un comportamiento particularmente estable, con las más bajas frecuencias en casi el total de las sesiones. La función declarativa sumó la segunda mayor frecuencia del total $(14.4 \%)$, seguida por las funciones otra $(11.8 \%)$ y la conativa (11.5\%). En conjunto, la función dudosa y la función-otra, que conforman el subgrupo de las comunicaciones sin función específica, sumaron una frecuencia absoluta del 23\%, lo cual las ubica, en bloque, como primera frecuencia bajo la función informativa.

No se identificaron correlaciones entre tipos de funciones y gestos o vocalizaciones totales. Se halló en cambio una correlación estadísticamente significativa $\left(r_{s}(14)=.735 ; p<.01\right)$ entre la función informativa y las palabras funcionales (encarnadas exclusivamente por adverbios de afirmación y negación) y entre la función actitudinal y estas mismas palabras $\left(r_{s}(14)=.820 ; p<.01\right)$. La función expresiva reveló también una correlación con la variable de las vocalizaciones no-palabra $\left(r_{s}(14)=.671 ; p<.01\right)$, resultado que se compadece con la condición precisamente de las vocalizaciones no-palabra en cuanto estas son manifestaciones de tenor emocional.

Al mismo tiempo, el análisis cualitativo de las particularidades semánticopragmáticas de las intervenciones del niño ha revelado rasgos de sus producciones sígnicas y sus funciones imposibles de apreciar en el análisis cuantitativo.

Para la función declarativa, afectada a la nominación, se encontraron casos de composiciones bimodales redundantes (mismo contenido semántico: pointing + verbalización 'esto') y de composiciones de palabra. En principio, podría parecer que estas dos variedades de composición son propias de la función informativa, por involucrar dos signos (formato para construcciones de carácter protoproposicional, una estructura ente-sujeto y atributo-predicado - 2;1 [28]: 'E_te - 


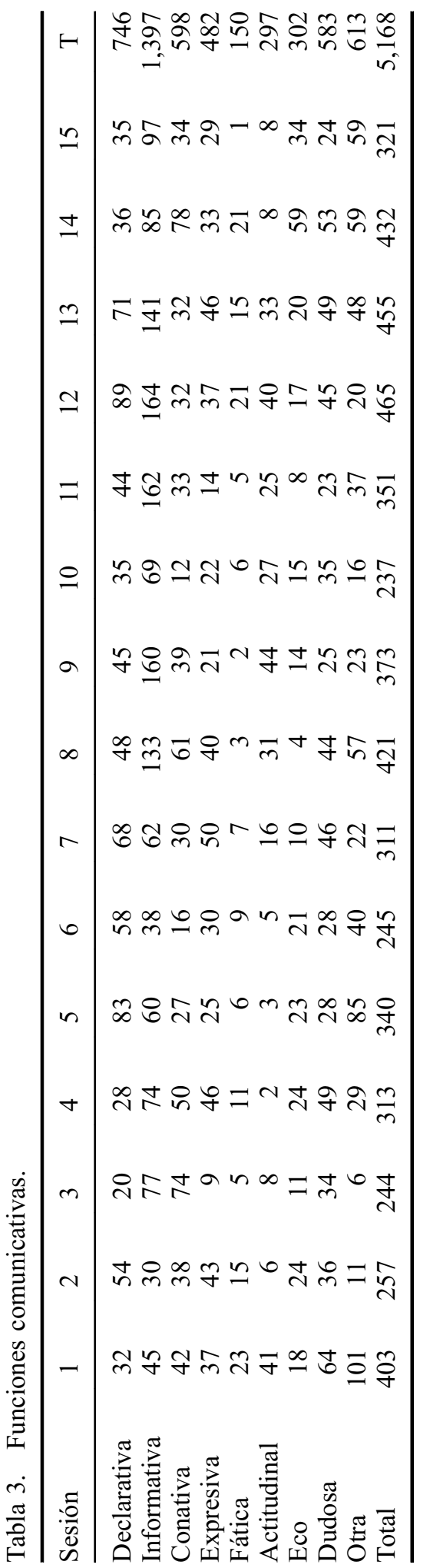


ande'/este [es] grande/). Sin embargo, las dos unidades pueden apuntar a la mera nominación (2;1 [28]: 'E_te auto': caso en que el demostrativo discrimina por proximidad el objeto mentado). El 'esto-aquí' en la base de toda emisión declarativa es diferente de la idea de un 'esto-así' ('Esto [es] grande') o bien del 'esto-tal' ('Esto [es un] perro'), casos en los que un signo informa sobre otro distinto signo (sujeto gramatical). Aunque lo más común en la función informativa es que se manifieste mediante composiciones, el estudio mostró que esto puede cumplirse con signos aislados. Una pregunta puede desplegar todos los contenidos de significado necesarios sin informar nada y la respuesta, en un segundo tiempo, ser el agente informativo aún si se trata de un solo elemento comunicativo. En 2;3 (25) el adulto interroga ‘¿De qué color es este lápiz?’ y el niño responde: 'Verde'. Es el saber del niño lo que, descontando en la interrogación los elementos que exponen la circunstancia, transforma el conjunto en una afirmación: /este lápiz es verde/. Lo mismo ocurre, ante la mera afirmación o negación: ‘¿Esto es azul?' | 'Sí'. La operación informativa es pues del niño, aun cuando su contribución, en términos enunciativos, corresponda sólo a una palabra.

La función conativa estuvo representada por órdenes y pedidos, verbales y gestuales, con signos aislados y compuestos (gestos de pointing, de pedir a mano abierta — request — o de exigir con acto de agarrar — reaching, grasping - solos o acompañados; en el acompañamiento era ubicado normalmente un verbo _ ' 'ame'/dame/ — el nombre del objeto o el pronombre respectivo, alternando entre 'yo' y 'mí').

La función expresiva se mostró encarnada en manifestaciones enfáticas gestuales u orales (palabra o interjección) en las que B daba a entender su estado emocional. En repetidas ocasiones palmeó sobre sus rodillas para dotar de potencia algún reclamo ('¡mío!', ‘¡eh!’), o elevó el tono de la voz hasta gritar (2;2 [10]: 'No toques' | 'Sí toque'/sí toco/), o lo aplacó para insinuar que era inocente al ser interpelado (2;2 [10]: ‘Quién se hizo caca?' | 'Ma_co'/Marco/ — dicho por el hermano, para desviar de sí mismo las sospechas).

La función actitudinal se hizo presente con intervenciones de rechazo/ aceptación mediante monosílabos ('sí', 'no'), que no son sin embargo retrucables como sí acontece en la función informativa. En 2;1 (5), el adulto propone: 'Vení, juguemos a la pelota' y B responde: 'Sí'. El elemento afirmativo no da información (descontando que en toda expresión se informa de algún modo), sino que revela, en B, su favorable predisposición. En 2;1 (5) el adulto pregunta a B si le cede su turno ('Ahora yo. ¿Puedo yo?') y B responde: 'No, yo'. B no ha informado más que de su voluntad ante la idea de que el adulto tome su lugar. No es función expresiva, si por tal se entiende la expresión de sentimientos con centro en el emisor; B deja conocer sencillamente su postura en relación con lo que el otro le propone.

La función fática se mostró en fórmulas convencionales de la lengua ('perdón', 'por favor') empleadas con solvencia desde el comienzo del período. Al recibir algún objeto de otro B decía invariablemente 'Iaia'/gracias/, pero nunca si era ayudado, o en retribución por diferentes prestaciones de las que 
pudiera ser beneficiario. Así, también participaba en ciertos juegos o conversaciones sin un involucramiento verdadero, interviniendo con palabras que no eran a veces más que muletillas para preservar el turno dentro de los intercambios. Por ejemplo, sabiendo perfectamente valerse del 'no', en ocasiones lo usaba sin contenido de significado para destinarlo a cuidar el canal. En 1;8 (3), preguntado acerca de su cuna (“¿Dónde está tu cuna?’), responde sin atender, compenetrado en otra cosa, 'No'. Algo más tarde, en la misma sesión, interrogado sobre qué prefiere: ‘Esto o esto?', volvió a replicar con 'No'. En $2 ; 3$ (19) se le pidió que se pusiera un gorro $\mathrm{y}$, para promover la acción, uno en particular que tenía a mano: 'Dame ese gorro'. B respondió, sin descuidar lo suyo y sin ser consecuente: 'Sí, doy', pero como si nunca hubiera estado en la conversación. Es como si hubiera advertido allí que era su turno para decir algo, y lo dijo, en este caso algo atinente, pero sin haberse involucrado.

Las intervenciones con función eco se reflejaron en todo tipo de repeticiones a las codas de las intervenciones del adulto. En 1;10 (9), jugando a tocar el fuego en un libro de ilustraciones, B no podía nombrarlo pese a las preguntas (“¿Qué es eso? ¿Cómo se llama?’). En lugar de responder, puso la mano en el dibujo y la retrajo con la exclamación de '¡Ay!' (como en señal de que eso quema). Preguntado entonces ‘Qué hizo el fuego?', B repitió tan sólo: '_eu_o/fuego/' (diptongo invertido y omisión de consonantes). Algo después, el interlocutor le relataba: 'El señor [del cueto] se inventó un helicóptero', de lo que B copió: 'O-có_te_o'/helicóptero/. En $1 ; 11$ (1), niño y adulto jugaban con un micrófono. Adulto: ‘¿Querés que lo apague?’; B, con determinación de hacerlo por sí mismo: '_pa_e'/apague/. En 2;1 (28), peleando por un muñeco, se le espetó: ‘¡Mi jugador, Bruno!', y él replicó: '_u_a_or'/jugador/. En 2;2 (29), comparando un conjunto de letras plásticas desparramado sobre el suelo, se le propuso reunirlas por pares por su semejanza: 'Así, juntas', y B: '-ntas'. Con el correr de la investigación, B comenzó a copiar frases más largas y complejas. En 2;5 (1), el adulto indicaba: 'Me parece que no', y él replicó: '-ece que no'. En la misma sesión, ante la afirmación: 'Es del mismo color', B reiteraba, con modulación perfecta: 'Es del mismo color'.

La función eco se tradujo igualmente en gestos. En 1;9 (17) B tocaba sobre un libro, sucesivamente y con gesto de pointing, las imágenes que antes tocaba el interlocutor, suerte de coda de la acción del otro. Esta gestualidad no informa, no es tampoco una expresión, nada pretende o pide, es simplemente una repetición ecoica de los gestos observados, un reconocimiento en primera persona del terreno que el otro ha señalizado por medio del nombre y la ostensión.

\section{Discusión}

Si bien se ha constatado una preferencia por la modalidad oral, la correlación entre las frecuencias totales de gesto y vocalizaciones permite interpretar que los comportamientos de una y otra modalidad mantienen sus proporciones y que el paulatino aumento de los signos orales no se realiza a expensas de los signos gestuales. En su predisposición a interactuar, el niño utilizará ambos recursos, con una marcada 
preferencia por la oralidad pero sin descuidar las posibilidades que ofrecen los gestos, y existiendo entre las dos modalidades una diferencia relativamente constante.

En materia de vocalizaciones, el aumento de las vocalizaciones-palabra y la constancia de las vocalizaciones ininteligibles invita a estimar que el crecimiento del vocabulario (la presumible y normal incorporación de palabras-tipo, no contabilizadas en esta investigación) y el crecimiento de palabras-caso (aumento de locuacidad) no inciden aparentemente en la frecuencia de signos mal modulados. Razonablemente puede suponerse que, a esta altura, el niño continúa ensayando con grupos fonémicos y con palabras cuya forma no acaba de dominar.

Que el período de dos palabras es una fase de transición cognitiva, plagado de ensayos y de intentos frustrados, lo avala también el hecho de que las funciones dudosa y otra, tomadas en conjunto, se ubiquen inmediatamente por debajo de la función con más alta frecuencia, la función informativa. Que la frecuencia de estas intervenciones se ubique tan próxima a las de funciones comunicativamente claras sugiere que en el período la producción semiótica del niño es todavía inmadura, insuficiente o imprecisa para conseguir plasmar los estados mentales que el sujeto quiere compartir con otros.

Las correlaciones entre las funciones informativa/actitudinal y las palabras funcionales permiten aventurar que, por un lado, la función informativa puede realizarse con respuestas del sujeto a las preguntas del interlocutor; por otro, que los mismos elementos funcionales sirven para brindar información y para manifestar una postura ante cierta propuesta. El 'no' y el 'sí' son tanto informativos (casos como: '¿Este juguete vuela? | No') como comunicadores de rechazo/aceptación (‘¿Querés pizza?’ | No’).

El análisis cualitativo permitió penetrar los rasgos cognitivos-funcionales bajo los empleos concretos de los signos. Las funciones declarativa e informativa, desdobladas a partir de la función referencial de Jakobson, se justifican en su utilidad diversa y en la complejidad mayor de la segunda en cuanto al procesamiento cognitivo, que supone unir dos signos con contenidos semánticos diferentes. Sin embargo, no parece atinado separar ambas funciones por la pauta de que a aquella corresponden enunciados de un solo elemento y a esta las composiciones de dos o más signos. La diferencia cognitiva no se debe traducir, por ende, en cantidad de signos expresados.

A la luz de los ejemplos, la función conativa continúa una rutina presemántica temprana en las interacciones bebé-adulto, las protoconversaciones (Trevarthen, 1980). Como en ellas, la acción expresiva, vocal o gestual, involucra a ambos interlocutores, con el añadido de que, desde la aparición del signo expreso, este proporciona la posibilidad de que los intercambios impliquen pedidos y exigencias. Así, es posible trazar una continuidad entre las protoconversaciones, los usos gestuales protoimperativos y protointerrogativos (Bates et al., 1975; Rodríguez, 2009) y el ida y vuelta conativo uni- y bimodal, aquí presente y ampliamente reconocido en las tipificaciones adultas.

La función expresiva, la primera en manifestarse ontogenéticamente (porque la biología dota al neonato de recursos como el llanto o la expresión facial), se 
reconvierte al mundo de los signos sin dejar atrás sus opciones más primitivas. En los primeros tiempos de la palabra, esta toma el relevo de las vocalizaciones no-léxicas sólo en ciertas oportunidades; en otras, tanto como sucede en el adulto, la expresión puede ser una interjección que, por volumen, tono, prosodia o contexto permita entender si corresponde a sorpresa, miedo o a alegría. Así pues, la función expresiva, la forma primaria y más espontánea de significar, progresa con todo el resto de signos en la marcha hacia la lengua, pero no renuncia nunca de modo definitivo a sus patrones conductuales primarios.

Por ello, nuestra discriminación de una función actitudinal distinta de la función expresiva parece justificada. La actitud del niño hacia una $u$ otra alternativas convidadas por el interlocutor no es confundible con la actuación espontánea de un estado de ánimo (Bühler, 1934). Si el rechazo/aceptación de estímulos es un comportamiento presente desde el comienzo, aquí la utilización de signos pone esa actitud en un plano de especialización semántica de nivel superior. Los ejemplos evidencian que las comunicaciones actitudinales no parecen poder reducirse a otras funciones comunicativas.

En relación con la función fática, hemos visto cómo $\mathrm{B}$ usaba signos anclados a algún contexto ('Iaia'/gracias/) o vaciados de semántica ('No'). En el primer caso, $\mathrm{B}$ revelaba estar en una fase donde el uso de este signo se hallaba ritualizado, sin comprender toda su variedad de aplicaciones. En relación con el segundo caso, intervención de todo punto inatinente, su empleo sólo parece interpretable como un ejercicio de guardar el sitio en la conversación. B sabia usar el 'no', pero también vaciarlo de significado y darle un uso idiosincrático. Nuevamente, el dispositivo de estos intercambios es el de las protoconversaciones: los diálogos de este momento no ocultan esa estructura arcaica presemántica. El 'no', tanto como otras muletillas deprivadas de su significación ('éste', 'acá', etc.), semejan un relicto de aquellos primeros intercambios fáticos.

La función eco, por su lado, parece al menos en parte comandada por un objetivo de incorporación de léxico. Ello concuerda con el hecho de que se repiten sobre todo las palabras nuevas (y finales) en la dicción del adulto. La función eco parece más tarde desaparecer en el hablante competente (salvo quizás en el aprendizaje de segundas lenguas), razón por la que quizás no se haya reparado en ella en las categorizaciones del lenguaje adulto. Al mismo tiempo, esta función no es exclusividad de la palabra, pero a diferencia de lo que ocurre con ella el gesto de eco no va necesariamente en pos de novedades. En todo caso, en el ejemplo 1;9 (17), cuando $\mathrm{B}$ realizaba un tacto sobre las imágenes del libro antes tocadas y eventualmente nombradas por el interlocutor adulto (una estructura interactiva repetida en otras oportunidades), la función eco parecía tener la comisión de elicitar procesos cognitivos de exploración. En el plano morfológico, podría hallarse aquí algún parecido con aquel denominado efecto imán (Rodríguez, 2007), consistente en despertar al niño el interés por tomar un objeto que le es enseñado. Sin embargo, a diferencia del caso canónico de efecto imán (niño alzando las manos para asir el objeto ofrecido mediante ostensión), aquí el objeto importa menos que el juego en sí mismo (tocar lo que el otro ya ha tocado simplemente porque lo ha tocado). Se trata más bien de una estrategia lúdica que implica (a) pasar por donde el otro ya ha pasado, (b) velar por 
una alternancia en las intervenciones (pervivencia del patrón primario protoconversacional), nunca tocando antes que el interlocutor. Mientras que el efecto imán parece implicar rigurosamente una acción de pedido (función conativa), en esta seguidilla aquí descripta se trata de un ida y vuelta gobernado por la pauta de la sucesión y cuidando reproducir en juego la acción del adulto.

\section{Conclusiones}

La colaboración entre modalidades (oral y gestual) tal como se puede apreciar en la Tabla 2 exhibe cómo el destino del habla-lenguaje, en tanto sistema relativamente autónomo de significación y comunicación, se consolida a partir de explotar, en un primer momento, los diferentes recursos-canales de la interacción con el adulto. De esta manera, los resultados de nuestra investigación se alinean con otros trabajos sobre el desarrollo semiótico temprano (Butcher \& Goldin-Meadow, 1993; Zlatev \& Andrén, 2009) y respaldan la teoría de un mecanismo de procesamiento semántico común al gesto y la palabra (McNeill, 1992, 2005).

En relación con las limitaciones del estudio, está claro que pesan sobre él las que la metodología suele identificar en estudios de caso: ser particularistas, descriptivos y heurísticos (Merriam, 1998). Ello significa, como es consabido, que no corresponde generalizar los resultados de nuestro trabajo empírico. La observación longitudinal no prueba hipótesis y nunca está libre del riesgo de reflejar sesgos de estilo personal, diferencias madurativas individuales y la incidencia no controlada de variables externas, "pero sí proporciona [...] la constricción científica por antonomasia’ (López Ornat, 1994, p. XVII), porque cualquier intento de explicación debe poder dar cuenta de esta evidencia recogida. Una prolongación muestral en curso nos permitirá poner a prueba las bondades de nuestro sistema clasificatorio. Por otra parte, estas limitaciones deben ponderarse considerando que se recogieron 7 1/2 horas de grabación de comunicaciones multimodales, con un total de 5,105 intervenciones vocales y gestuales simples y compuestas, para un período relativamente poco estudiado, dentro del cual se aplicaron categorías para funciones nunca antes estudiadas.

La investigación realizada ha aportado evidencia del comportamiento de los usos comunicativos del período de dos palabras contemplando por igual las comunicaciones con signos orales (vocalización, palabra) y con signos gestuales. Para optimizar la exploración del período estudiado, momento crucial dentro del desarrollo ontogenético de las habilidades comunicativas, fue elaborado un código de observación atento a clasificaciones precedentes pero acomodado a nuestros objetivos. Se hizo evidente la necesidad de incorporar nuevas categorías para cubrir funciones comunicativas no reconocidas en la bibliografía especializada. Mucho se ha escrito en relación con los progresos de los tipos de signo, mucho menos sobre los avatares de las funciones comunicativas. El código suple a su vez un déficit de máxima importancia en el terreno práctico, a saber, la carencia de unas definiciones nominales y operacionales claramente detalladas. La falta de formulación explícita aquí subsanada brinda a futuras investigaciones la opción de una base clara 
para decidir si una particular intervención del niño operacionalmente corresponde a una determinada función comunicativa, tanto como la posibilidad de reevaluar esta categoría y redefinirla, si fuera preciso, alternativa sólo habilitada por la transparencia que hemos perseguido.

Las funciones clásicas del lenguaje (Jakobson, 1960), extendidas en nuestra investigación sobre todo el espectro comunicativo, se encuentran en general dentro del repertorio de usos que $\mathrm{B}$ exhibe desde comienzos del período estudiado, con excepciones para las funciones poética, metalingüística y ejecutiva. La separación, que creemos justificada, de la función referencial en declarativa e informativa, y la incorporación de las funciones actitudinal y eco son contribuciones que hacen justicia a un período decisivo en el proceso de la adquisición de la lengua. La distinción entre función declarativa/informativa es importante porque honra las diferencias entre nombrar y decir, entre ordenar el mundo en las categorías de la palabra y efectuar predicaciones (discriminación aristotélica reivindicada por Coseriu frente a un siglo XX demasiado concentrado en los aspectos descriptivo-proposicionales del lenguaje y olvidado del rol esencial de la palabra antes de su inserción en estructuras de porte mayor Coseriu, 2015). La separación es doblemente relevante cuando se trata de explorar el desarrollo ontogenético de la expresión del niño, habida cuenta de que entre la alusión y la proposición media un sensible salto cognitivo.

La función actitudinal se ha revelado como una categoría distinta de la de función informativa, ya que no informa sino de una predisposición de corte subjetivo, y de la expresiva, por cuanto la subjetividad en juego no es aquí de contenidos fundamentalmente emocionales sino de intercambios proposicionales. Con ello, la función actitudinal aporta novedad a los estudios clásicos y más recientes en lingüística y psicología del desarrollo (Bruner, 1981; Halliday, 1975; Murillo \& Belinchón, 2013).

También se mostró acertado discernir la función eco, consistente en las repeticiones de alguna expresión del otro, y haberla discriminado de la función fática (ya que no aquélla no tiene la intención de cuidar el canal sino la de integrar al reservorio léxico un nuevo elemento). En algún punto, esta función entra en la lógica del tipo de reiteración que en la memoria de trabajo corresponde al subsistema del lazo articulatorio o bucle fonológico (Baddeley, 2003), que recapitula inputs verbales para prolongar la vida efímera de estos estímulos. La diferencia es que aquí el ejercicio no busca extender el tiempo durante el que una palabra se encuentre a disposición, sino agregarla al léxico mental. Un objetivo de la función eco es, por lo tanto, la memoria de más largo plazo. En la proporción en que el bucle fonológico parece también estar relacionado con la adquisición del sistema de signos del lenguaje oral (Baddeley, Gathercole, \& Papagno, 1998), la utilidad visible de la función eco y el procesamiento mudo que tiene lugar regularmente en la memoria de trabajo pueden verse como aliados en el cometido de gestar la lengua en el sujeto. La función eco es pues una categoría importante para las teorías de adquisición lingüística como un proceso ontogenético gradual no-lineal (López Ornat et al., 1994) que implica un componente de ensayo y repetición.

En resumen, el comportamiento de las vocalizaciones y los gestos permite avalar una co-dependencia en el progreso de las expresiones y, contra la expectativa, no 
deja lugar a suponer que el incremento en el uso de signos de modalidad oral suceda a expensas de la frecuencia de gestos. La unimodalidad de las expresiones verbales se deja entender entonces como una derivación de la multimodalidad originaria. La autonomización de la palabra no borra el origen prelingüístico de las funciones de la comunicación y de la vocación social que se ubica en el nervio de la subjetividad humana. La comunicación lingüística es declarativa, informativa, conativa, expresiva, fática, actitudinal y ecoica (más otras funciones de aparición ulterior), pero, en rigor, las vocalizaciones y los gestos ya habrán explorado todas estas posibilidades para cuando la palabra devenga gramatical y conquiste un espacio cada vez más protagónico.

\section{Disclosure statement}

No potential conflict of interest was reported by the authors. / Los autores no han referido ningún potencial conflicto de interés en relación con este artículo.

\section{References / Referencias}

Andrén, M. (2010). Children's Gestures from 18 to 30 Months (Unpublished Doctoral Dissertation). Centre for Languages and Literature, Lund University, Lund.

Austin, J. L. (1962). How to do things with words. Oxford: Clarendon Press.

Baddeley, A. (2003). Working memory and language: An overview. Journal of Communicational Disorders, 36, 189-208.

Baddeley, A., Gathercole, S., \& Papagno, C. (1998). The phonological loop as a language learning device. Psychological Review, 105, 158.

Bates, E., Camaioni, L., \& Volterra, V. (1975). The acquisition of performatives prior to speech. Merrill-Palmer Quarterly of Behavior and Development, 21, 205-226.

Brown, R. (1973). A first language. Cambridge, MA: Harvard University Press.

Bruner, J. (1981). The social context of language acquisition. Language and Communication, 1, 155-178.

Bühler, K. (1934). Teoría del lenguaje. (Trad. J. Marías). Madrid: Alianza.

Butcher, C., \& Goldin-Meadow, S. (1993, March 25-28). From one spoken word to two: Exploring the changing nature of gesture. Paper presented at the Biennial Meeting of the Society for Research in Child Development (60th), New Orleans, LA. doi:10.1111/j.1467-8624.1996.tb01758.x

Clark, R. A. (1978). The transition from action to gesture. In E. A. Lock (Ed.), Action, gesture and symbol: The emergence of language (pp. 231-257). London: Academic Press.

Cochet, H., \& Vauclair, J. (2010). Pointing gestures produced by toddlers from 15 to 30 months. Infant Behavior and Development, 33, 431-441.

Coseriu, E. (2015). Geschichte der Sprachphilosophie. Tübingen: Narr Francke Attempto.

Crais, E., Douglas, D., \& Campbell, C. (2004). The intersection of the development of gestures and intentionality. Journal of Speech, Language and Hearing Research, 47, 678.

Delgado, B., Gómez, J. C., \& Sarriá, E. (2010). Funciones tempranas del gesto de señalar privado: La contemplación y la autorregulación a través del gesto de señalar. Acción Psicológica, 7, 59-70.

Dupertuis, V., \& Moro, C. (2016). Self-directed ostensions and mediations of the adult at the age of 8-, 12- and 16 months. Integrative Psychological Behavior, 50, 621-633.

Español, S. (2004). Cómo hacer cosas sin palabras. Madrid: Antonio Machado. 
Español, S. (2006). Possible precursors of private speech: Deictic, symbolic and aesthetic self-directed gestures. In I. Montero García-Celay (Ed.), Current research trends in private speech. Proceedings of the First International Symposium on Self-Regulatory Functions of Language (pp. 120-124). Madrid: Ediciones de la UAM.

Español, S., Bordoni, M., Martínez, M., Camarasa, R., \& Carretero, S. (2015). Forms of vitality play and symbolic play during the third year. Infant Behavior \& Development, 40, 242-251.

Esteve-Gibert, N., \& Prieto, P. (2013). Prosody signals the emergence of intentional communication in the first year of life: Evidence from Catalan-babbling infants. Journal of Child Language, 40, 919-944.

Forrester, M. (2010). Emerging musicality during the preschool years. Psychology of Music, 38, 131-158.

Forster, S., \& Iacono, T. (2013). The nature of affect attunement used by disability support workers interacting with adults with profound intellectual and multiple disabilities. Journal of Intellectual Disability Research, 58, 1105-1120.

Halliday, M. A. K. (1975). Learning how to mean. London: Edward Arnold.

Hernández Pina, F. (1984). Teorías psicosociolingüísticas y su aplicación a la adquisición del español como lengua materna. Madrid: Siglo XXI.

Hernández Sampieri, R., Fernández Collado, C., \& Baptista Lucio, P. (2006). Metodología de la investigación. México: McGraw-Hill.

Jakobson, R. (1960). Linguistics and poetics. In T. A. Sebeok (Ed.), Style in language (pp. 350-377). Cambridge: MIT Press.

Jonsson, C. O., Clinton, D., Fahrman, M., Mazzaglia, G., Novak, S., \& Sörhus, K. (2001). How do mothers signal shared feeling-states to their infants? An investigation of affect attunement and imitation during the first year of life. Scandinavian Journal of Psychology, 42, 377-381.

Kerbrat-Orecchioni, C. (1986). La enunciación. De la subjetividad en el lenguaje. Buenos Aires: Hachette (1980).

López Ornat, S. (1994). La metodología de la investigación longitudinal. In S. López Ornat, A. Fernández, P. Gallo, \& S. Mariscal (Eds.), La adquisición de la lengua española (pp. 3-12). Madrid: Siglo XXI.

López Ornat, S., Fernández, A., Gallo, P., \& Mariscal, S. (1994). La adquisición de la lengua española. Madrid: Siglo XXI.

Martínez, I. C., Español, S., \& Pérez, D. (2018). The interactive origin and the aesthetic modelling of image-schemas and primary metaphors. Integrative Psychological and Behavioral Science. doi:10.1007/s12124-018-9432-z

McNeill, D. (1992). Hand and mind. Chicago, IL and London: University of Chicago Press.

McNeill, D. (2005). Gesture and thought. Chicago \& London: University of Chicago Press.

Merriam, S. (1998). Qualitative research and case study applications in education. San Francisco, CA: Jossey-Bass.

Murillo, E., \& Belinchón, M. (2013). Patrones comunicativos multimodales en la transición a las primeras palabras: Cambios en la coordinación de gestos y vocalizaciones. Infancia y Aprendizaje, 36, 473-487.

Piaget, J. (1937/1988). La construcción de lo real en el niño. (Trad. R. Santamaría). Barcelona: Crítica.

Rivière, Á., \& Español, S. (2003). La suspensión como mecanismo de creación semiótica. Estudios de Psicología, 24, 261-275.

Rivière, A., \& Sotillo, M. (1999). Comunicación, suspensión y semiosis humana: Los orígenes de la práctica y de la comprensión interpersonales. In Á. Rivière (Ed.), Obras escogidas (Vol. 3, pp. 181-202). Madrid: Panamericana. 
Rodríguez, C. (2007). El ojo de Dios no mira signos. Desarrollo temprano y semiótica. Infancia y Aprendizaje, 30, 343-374.

Rodríguez, C. (2009). The 'circumstances' of gestures: Proto-interrogatives and private gestures. New Ideas in Psychology, 27, 288-303.

Rodríguez, C., Moreno-Núñez, A., Basilio, M., \& Sosa, N. (2015). Ostensive gestures come first: Their role in the beginning of shared reference. Cognitive Development, $36,142-149$.

Rodríguez, F. G. (2017). La comunicación humana antes de la gramática (Unpublished Doctoral Dissertation). Universidad de Buenos Aires, Buenos Aires.

Rodríguez, F. G., \& Español, S. (2016). Bimodal compositions of gesture and vocalization at the beginning of verbal communication. Infancia y Aprendizaje, 39, 661-693.

Romero Andonegi, A., Etxebarria Lejarreta, A., de Pablo Delgado, I., \& Romero Andonegi, A. (2017). Interrelación entre gestos y vocalizaciones en funciones comunicativas tempranas: Evidencias desde la lengua vasca. Revista Signos, 50(93), 96-123.

Sarriá Sánchez, E. (1991). Observación de la comunicación intencional preverbal: Un sistema de codificación basado en el concepto de categoría natural. Psicothema, 3, 359-380.

Strauss, A., \& Corbin, J. (1998). Basics of qualitative research: Techniques and procedures for developing grounded theory. Los Angeles, CA: Sage.

Tomasello, M., Carpenter, M., \& Liszkowski, U. (2007). A new look at infant pointing. Child Development, 78, 705-722.

Trevarthen, C. (1980). The foundations of intersubjectivity: Development of interpersonal and cooperative understanding in infants. In D. R. Olson (Ed.), The social foundation of language and thought (pp. 316-342). New York, NY: Norton.

Zlatev, J., \& Andrén, M. (2009). Stages and transitions in children's semiotic development. In J. Zlatev, M. Johansson Falck, C. Lundmark, \& M. Andrén (Eds.), Studies in language and cognition (pp. 380-401). Newcastle: Cambridge Scholars Publishing. 